\title{
Yield Spread Determinants of Sukuk and Conventional Bonds
}

\begin{abstract}
Despite increased economic turmoil over the past few years, the Islamic financial sector including sukuk has shown tremendous growth and stability. This study examines the yield spread determinants of sukuk and conventional bonds. We comparatively assess the effects of firm- and industry-specific variables, bond characteristics, and macroeconomic conditions on the yield. Our sample data features bonds and sukuk of different maturities issued by 58 publicly traded (listed) firms in Malaysia. For sukuk, primary determinants are the firm-specific indicators which indicate lower yield spreads. Moreover, sukuk spreads do not widen with equity volatility, making them less risky than conventional bonds. For conventional bonds, both firmlevel and bond-specific characteristics significantly affect yield spreads. Higher financial leverage with shorter maturity is associated with low yields and low spreads. Findings in this study present new insights and important policy implications for investors trading in and regulators governing sukuk and conventional bonds.
\end{abstract}

Keywords: sukuk; Islamic bonds; conventional bonds; yield spreads.

Classification Codes: E44, G15, N20, F30 


\section{Introduction}

For private companies, the relative cost of finance is a key driver of economic growth, while corporate bond yield spreads (i.e., the difference between corporate $s u k u k /$ bond yields and the riskfree rate of each maturity) are associated with the general economic climate (see Cavallo and Valenzuela, 2010). Further, risk premia, which inversely vary with the readiness to incur risk, are reflected in corporate yield spreads (see Gebka et al., 2018; Liu et al., 2009; Collin-Dufresne et al., 2001). For instance, the yield spreads of corporate bonds widen and tighten because of various reasons, such as the changing risk tolerance of market participants, the supply and demand in a corporate bond market, and so forth.

When investors become more reluctant to take risks, the risk premium can increase, and vice versa. Meanwhile, corporate yield spreads tend to change in the same direction, and their variations are highly correlated. Thus, studying which factors affect such spreads is important for a wide range of participants in the financial market. Specifically, it is not only helpful for bond issuers to improve pricing (since it enhances efficiency in the market for corporate bonds) but also for policymakers enacting prudential measures to control credit risk in the bond market. As for the behavior of corporate yield spreads, it has received significant attention from practitioners, financial regulators, and researchers. However, several research questions remain. To what extent are corporate and government yields associated with default risk and bond-specific characteristics? Which macroeconomic factors are associated with variations in corporate yield spreads?

Adding to the general interest is the rapid growth of Islamic banking and finance. Islamic finance assets have shown a compound annual growth rate (CAGR) of $4 \%$ since 2012, with capital market assets as the fastest-growing assets. Regarding sukuk, it is the second fastest-growing asset class, with a CAGR of 7\% since 2012 (Abdelsalam et al., 2020). Many salient features of sukuk (e.g., time to maturity, the coupon rate, trades on the normal yield price relationships, etc.) are identical to those of conventional bonds (see Wilson, 2008). Yet, there are controversies and myths regarding the differences between conventional bonds and sukuk. Although empirical studies have indicated the differences between their respective yields, the relevant factors have been neglected (Safari and Ariff, 2014). Moreover, these studies not only failed to provide a wider range of determinants of yield movement (causing the issuer to default on payment), but they also failed to compare the underlying factors affecting sukuk yields with that of conventional bonds. It is 
important to note that sukuk have an innovative and flexible structure compliant to the Sharia principles while avoiding the riba, gharar, maisir, and other prohibited elements. Consequently, sukuk have a different pattern of yield spreads as opposed to conventional bonds (Saad et al., 2020).

By analyzing the yield spreads of securities, the following research questions are addressed: (1) Are there any significant variations in the yield spreads of securities relevant to understanding the determinants of relative credit risk?; and (2) Are sukuk merely a camouflaged version of conventional bonds? Overall, the focus is upon firm-specific variables, industry-specific variables, bond characteristics, and macroeconomic conditions. The sample in this study consists of 206 Malaysian bonds (62 sukuk and 144 conventional bonds) issued by 58 publicly traded (listed) firms from 2002 to $2013 .{ }^{1}$ For the purpose of this study, the Malaysian market offers an interesting setting for several reasons. First, the Malaysian market is the most active in terms of sukuk issuances. Second, Malaysian sukuk accounts for $49 \%$ of the total outstanding sukuk (see ICD Thomson Reuters, 2015). Finally, it represents approximately half of the total stock of Malay corporate bonds (see Jobst et al., 2008). ${ }^{2}$

\section{[Insert Figures 1a and 1b here]}

According to our findings, when comparing the variances in the spread of conventional bonds and sukuk, the explanatory power of different determinants is evident. The analysis of the entire sample also indicates that for sukuk, firm-level characteristics, such as size, profitability, and interest coverage ratios, are closely associated with lower sukuk spreads. Meanwhile, for conventional bonds, both leverage and volatility are associated with yield spreads. Unlike conventional bonds, sukuk spreads do not widen with equity volatility. In short, sukuk appear to be less risky than conventional bonds. Additionally, one bond-related characteristic (e.g., the remaining time to

\footnotetext{
${ }^{1}$ Our preliminary analysis showed that for a long period of time, sukuk issues in the Middle East and other Muslim populated regions were minimal, which could have led to data anomalies in our analysis. Thus, we focused on the Malaysian bond market. Additionally, we were unable to obtain a similar data frequency for 3-, 5-, 7-, and 10-year maturity sukuk and bonds in the same time period for other countries.

2 The issuance of bonds in Malaysia has faced strong demand from all investors. The adoption of a special provision for non-profit trusts, similar to the English law that facilitates the establishment of special purpose vehicles (SPVs) (which are required to hold the title of underlying securitized assets and administering payments to investors), are among the steps taken by the Malaysian authorities to stimulate this growth.
} 
maturity) shows a significant negative relationship for both securities. However, the interaction between debt and the remaining time to maturity is only significant for conventional bonds. The positive coefficient of the interaction term for both securities also indicates that firms with high leverage do not benefit from long-maturity bonds. Furthermore, although the interaction between debt and the remaining time to maturity is significant for conventional bond spreads, no similar pattern exists for sukuk.

These results contribute to the literature in the following ways. First, it uniquely implements an empirical methodology that utilizes panel data techniques to reveal the determinants of corporate risk while mitigating cross-sector heterogeneity in the sample. Second, there have been relatively few comparisons of the yield spreads of bonds and sukuk. Hence, with its focus on the different maturities and bonds issued by the 58 Malaysian companies, comparisons can be drawn from the behaviors in the United States (U.S.) and European bond markets. Third, this study extends the work of Hassan et al. (2018) and Maghyereh and Awartani (2016). While Hassan et al. (2018) highlighted the relevance of market-wide factors, Maghyereh and Awartani (2016) examined the returns and volatility spillovers of sukuk and global corporate bonds. Fourth, in showing that sukuk yield spreads are less associated with macroeconomic factors than conventional bonds, we extend the research of Ramasamy et al. (2011). Finally, our findings suggest that Islamic equities and sukuk provide a "cushion" against risk and instability, thus confirming the findings of Kenourgios et al. (2016).

The remainder of this study is as follows. The next section includes a literature review, a description of both sukuk specifications, and a discussion on the theory underpinning our methodology and econometric framework. Section 3 outlines the hypothesis development, while Section 4 presents the data sample. Section 5 discusses the empirical design and framework, while Section 6 summarizes the results of the panel econometric model, the sensitivity analysis, and the variance decomposition analysis. Finally, Section 7 provides the conclusion.

\section{Background}

\subsection{Related Literature}

The growing literature on sukuk over the past two decades (e.g., Paltrinieri et al., 2019; Amrani et al., 2017; Zulkhibri, 2015) highlights the increasing importance of investigating the structure of these bonds. Specifically, these studies mainly focused on the growth of sukuk, conducted analyses 
on the theoretical aspects of sukuk, and made comparisons of sukuk vis-à-vis conventional bonds. These studies also examined sukuk and stock market behaviors. Overall, such literature can be classified into three aspects: (1) Comparing the business models of sukuk and bonds; (2) Examining the determinants of the issuance of sukuk; and (3) Exploring the stock market perspective of sukuk and bonds as well as the linkages between their respective markets. Jobst (2007) was among the first analysts to discuss the legal and economic implications of Sharia compliance for the configuration of sukuk. He even predicted a strong demand from both Islamic countries and conventional financial institutions for Sharia-compliant securities.

The finding that sukuk brings diversification advantages is consistent with the finding that measured value-at-risk is lower for a portfolio that includes sovereign sukuk and Eurobonds, compared to a portfolio containing only the latter (Cakir and Raei, 2007). For a similar comparison of riskiness, the duration and convexity of sukuk and conventional bonds was assumed to approximate the value lost or gained in a portfolio (Ramasamy et al., 2011). ${ }^{3}$ Their findings also showed that both convexity and duration measures perform better for sukuk, as their risk is relatively lower.

Another strand of literature focused on the determinants of sukuk issuance. Thus, the choice of this financing tool is accordingly subordinate to normal debt finance but prior to equity issuance. Godlewski et al. (2013) examined the relative risk-reduction advantages of issuing sukuk over conventional bonds in the Malaysian market. They found that the stock market is neutral to announcements of bond issues, but it negatively reacts to announcements of sukuk issues. They attributed this to excess demand for sukuk, while lower-quality debtor companies explained the difference in the stock market reactions as an adverse selection mechanism that favors sukuk issuance. Hanifa et al. (2014) compared the use of sukuk with that of conventional bonds by firms targeting debt optimization. Based on the issuance of 120 conventional bonds and 80 sukuk from 2000 to 2011, they utilized partial adjustment models to reveal the determinants of the firms' debt target ratios as well as the dynamic adjustment behaviors for the sukuk issuance and its subcategories. First, their results showed that the trade-off benefits for sukuk issuers differ from those of bond issuers. Second, the issuers of partnership-based sukuk and convertible bonds closely follow the pecking-order theory, in which the former is chosen if firms face higher information

${ }^{3}$ Convexity estimates reflect the change in duration when the yield rate changes. 
asymmetry costs. Finally, while both exchange-based sukuk and straight bond issuers focus on a particular target, firms with higher sales growth tend to prefer the former.

The third strand of literature explored sukuk and bonds from the stock market perspective, including the co-movements and linkages between the stock and bond market (Aloui et al., 2015a; Sclip et al., 2016; Maghyereh and Awartani, 2016; Naifar et al., 2016), the co-movement dynamics between sukuk and conventional bonds (Hassan et al., 2018), the structural changes in the stock market affecting the bond market (Aloui et al., 2015b), and the interest rate effect on the sukuk market (Akhtar et al., 2017). Specifically, Aloui et al. (2015a) investigated the co-movement mechanism between sukuk and Islamic stock indices in the Gulf Cooperation Council (GCC) countries. Using time-frequency analysis, they found a strong dependence between the Islamic stock market indices and sukuk. They also provided evidence of a strong negative correlation between the Islamic stock market and sukuk market. For instance, in the dynamic conditional correlation (DCC), the level of correlation increased because of the contagion effect of a global financial crisis. Additionally, although the degree of co-movement varied across time and frequency, the long-run horizon was dominant. Using the GARCH-DCC model, Sclip et al. (2016) investigated the dynamic linkages between the sukuk and conventional markets, providing evidence of a high correlation between the former and the latter. Moreover, they argued that investors can achieve portfolio diversification by investing in sukuk, given their lower volatility. However, they also referred to sukuk as a "hybrid security" between equity and bonds. Conversely, Maghyereh and Awartani (2016) highlighted the difference between sukuk and conventional bonds by investigating the returns and volatility spillovers of sukuk and global bonds with equities. They not only identified a different transmission mechanism among both markets but also found that the sukuk market has a higher transmission of information from equities. However, the return and volatility diffusion of the sukuk market was relatively small and trivial, compared to other financial markets.

Akhtar et al. (2017) investigated the impact of interest rate announcement news on sukuk, the conventional bond market, and the Islamic and conventional stock markets. They found that such news has a negligible impact on the sukuk market, compared to their conventional counterpart. However, the interest rate news has a greater impact on the Islamic stock market than on the conventional one. In a similar vein to that of Maghyereh and Awartani (2016), Hassan et al. (2018) 
investigated the determinants of co-movement dynamics between sukuk and conventional bonds. They analyzed the conditional correlations and volatility linkages between the sukuk and conventional bond markets and found that sukuk and conventional investment-grade bonds have a lower reaction of conditional volatility to market shocks and that sukuk returns are much less volatile than U.S. and European investment-grade bonds. However, they found a time-varying, positive, and conditional correlation between sukuk returns and leading bond markets, driven by the changing macroeconomic and market conditions. Additionally, they revealed that during recessions, the dynamic correlation between sukuk and bond markets tends to increase. Their study is one of the few that not only compares the correlation and volatility of sukuk returns with that of U.S. and European bond markets but also highlights the market-wide factors affecting bonds and sukuk returns. Moreover, their objectives appear to resonate with the purpose of the present study in that it investigates how the determinants of the returns in both types of securities compare with one another.

A thorough review of the empirical and theoretical studies on sukuk shows that there is no study to date which has analyzed and identified the risk premia of conventional bonds and sukuk, as measured by yield spreads. Furthermore, none of the prior studies have investigated the dynamic behavior of corporate bond credit spreads in the conventional fixed-income and sukuk market. According to Loncarski et al. (2012), this area remains unscathed and warrants key attention as it can help investors and policymakers identify the factors that influence the credit spreads of both types of securities and make informed decisions in choosing sukuk over conventional bonds, and vice versa. Therefore, the present study extends the previous research by analyzing the determinants affecting the yield spreads of these two types of securities. It also investigates the relevance of firm- and bond-specific variables as well as the macroeconomic factors in such spreads by focusing on the Malaysian sukuk and bond market.

\subsection{Stylized Facts of Sukuk}

In Islamic finance, three requirements are necessary to comply with Sharia law (Godlewski et al., 2013): (1) The instrument must represent ownership in tangible assets, usufruct, or services from revenue-generating firms; (2) Payments to the investor must accrue from after-tax profits; and (3) The value repaid on maturity must follow the current market price of the asset, not the original amount invested. Table 1 indicates the differences between sukuk and conventional bonds. Like 
conventional asset-backed securities (ABS), sukuk are backed by assets. The difference is that the underlying assets for ABS can be financial assets, such as loans or other receivables, while only real assets may serve as collateral for sukuk. By implication, the value of sukuk is solely determined by the performance of relevant real assets (AAOIFI, 2008). Meanwhile, sukuk prices can vary based on the creditworthiness of the issuer and the market value of the underlying assets (Godlewski et al., 2013). Therefore, sukuk, (especially partnership sukuk such as musharkah and mudarbah sukuk) are akin to an equity instrument rather than a debt instrument. As for the yield spreads of sukuk, they are determined by firm-level characteristics rather than macroeconomic or sukuk-specific characteristics.

\section{[Insert Table 1 here]}

The ongoing debate in which the extent to which sukuk instruments are closer to conventional debt than equity finance often turns into a distinction between asset-based or asset-backed sukuk (see Abdelsalam et al., 2020). With asset-based sukuk, the principal is supported by the capital value of the asset, but the returns and repayments are not directly financed from the asset. In substance, asset-based sukuk are the same as equity. For asset-backed sukuk, the principal as well as the returns and repayments are directly financed from the asset. In this case, as it offers investors neither income nor capital guarantees, there can be no default. Overall, the key difference between asset-based and asset-backed sukuk is the concept of true sale. In asset-backed sukuk, there is a true sale between the originator and the special purpose vehicle (SPV). Moreover, the assets are owned by the SPV, the returns are derived from the assets, and the asset prices vary over time. It is important to note that the majority of sukuk are not asset-backed. (Hayat, 2010).

\section{The Determinants of Credit Spreads and Hypothesis Development}

The extensive literature on yield spreads falls into three strands. The first strand analyzes the default component, which is assumed to be endogenously determined by the issuer's balance sheet (Longstaff and Schwartz, 1995). The second strand applies a reduced-form model (Jarrow and Turnbull, 1995), in which yield spreads are assumed to be exogenously determined by the default probability and expected recovery rate. The third strand regresses the spreads according to variables, mainly derived from the structural and reduced-form models. These range from macroeconomic conditions and bond-level variables to firm-specific information. Previous 
research on these theoretical models (Cavallo and Valenzuela, 2010; Peter and Grandes, 2005) have also indicated that they have difficulties explaining the observed credit spreads for different maturity issuances, especially those with similar firm performance behavior and the observed term structure of credit spreads. However, they do highlight some potential determinants of such spreads.

Thus, we consider the major factors driving credit spreads, from both theoretical and empirical viewpoints, to distinguish between the bond-specific and common factors that affect all corporate bonds and sukuk. As these theoretical implications can be empirically tested, we analyzed the effects of the variables in the three different categories on the change in yield spreads.

\subsection{Firm Characteristics and Credit Spreads}

Firm-level characteristics, such as the size, capitalization ratio, leverage ratio, profitability, and stock volatility, may be more relevant to yield spreads for the quasi-equity nature of sukuk than to corporate bonds. For example, if small firms exhibit longer earnings depressions than large firms, then relative size might indicate a negative relationship between size and returns. Conversely, small firms may require larger coverage ratios to achieve the same credit rating as larger firms. In addition, as large firms are better situated to accommodate risk than small firms, the yield spreads may be lower for the former. From their investigation on the impact of investors' expectations of future debt, Flannery et al. (2012) found that expected increases in future leverage can result in higher credit spreads. However, as leverage is limited for Islamic securities, this factor is less likely to affect sukuk yield spreads.

Accordingly, we conjecture a positive association between the volatility of a firm's value and credit spreads (see Collin-Dufresne et al., 2001). Moreover, relatively higher asset-value volatility carries a higher probability of a subsequent drop. Thus, the first hypothesis is as follows:

Ho1: Firm-level characteristics (i.e., the high-interest coverage ratio, the high returns on assets (ROA), and large size) significantly decrease sukuk and bond spreads, while other firm characteristics (capitalization, volatility, and leverage) significantly widen such spreads. 


\subsection{Bond Characteristics and Credit Spreads}

A bond's time-to-maturity, indicating a firm's debt maturity structure, can also explain an important proportion of corporate bond spreads (Valenzuela, 2016). In principle, this most likely holds true for sukuk. According to Longstaff et al. (2005), the rationale for using this variable is that there might be maturity-sensitive clientele for conventional corporate bonds.

The economic intuition is that, if both value-volatility and firm-value are high, then as the time to maturity shortens, the leverage or the risk of default (hence, the spread) rises (see Peter et al., 2005). Accordingly, the longer the time to maturity, the more opportunities a firm has to increase earnings and reduce leverage. Moreover, there is relevance with regard to time to maturity, and the interaction between time to maturity and leverage in the yield spreads for both bonds and sukuk. Hence, the second hypothesis is as follows:

\section{Ho2: Conventional corporate bonds and sukuk with longer maturities exhibit higher spreads for firms that are highly leveraged and have high-equity volatility.}

\subsection{Macroeconomic Conditions and Credit Spreads}

Previous research has found that conventional corporate bond yield spreads tend to fluctuate with business cycles. For example, Fama and French (1993) showed that credit spreads widen as economic conditions weaken, while Duffie et al. (2007) indicated that macroeconomic variables tend to be correlated with default rates and yield spread changes. Further, Elton et al. (2001) argued that corporate bond credit spreads may be explained by factors commonly used to model risk premia for common stocks. In related studies, Tang and Yan (2006), David (2008), and Chen et al. (2007) showed how default probability and credit spreads decline as economic growth rises. Calculated as the difference between 10- and 2-year bonds, the slope of the yield curve has also been cited as a predictor of credit spreads (Krishnan et al., 2010). Furthermore, as the future probability of default decreases when the expectation of the future interest rate increases, the credit spread narrows (Collin-Dufresne et al., 2001). Accordingly, our third hypothesis is as follows:

\section{H03: Macroeconomic factors have significant effects with similar magnitudes on the change in yield spreads for both types of bonds.}




\section{Data and Variable Description}

\subsection{Data Coverage and Sources}

From the Bloomberg Professional database, we drew a sample of 206 bonds (62 sukuk and 144 conventional bonds) with different maturities (3-, 5-, 7-, and 10-year), issued by 58 companies across six Malaysian sectors from 2002 to 2013 (see Tables 2(a) and 2(b)). As firm-specific variables are typically reported on a quarterly basis, bond and sukuk prices are reported daily. Thus, the latter were transformed into quarterly frequency by computing the corresponding period average. ${ }^{4}$ As for the sample selection, it was constrained by data availability and the necessary screening to meet the filter criteria. ${ }^{5}$ Finally, balance-sheet level information was extracted from Bursa Malaysia's website, while the Refinitiv Datastream and the International Financial Statistics database of the International Monetary Fund (IMF) were used for the macro data.

\section{[Insert Tables 2(a) and 2(b) here]}

\subsection{Dependent Variable}

The dependent variable was the short form of the yield spread over the benchmark curve. The yield spread on a corporate bond/sukuk is defined as the difference between the yield to maturity (YTM) of the corporate bond, minus the YTM of a comparable-maturity, default-free instrument. The default-free instrument used in this study was the Malaysian Government Security (MGSY) benchmark index for 3-, 5-, 7-, and 10-year maturities.

The YTM or gross redemption yield is the most commonly used measure of the return from holding a bond. It is also used as a proxy for measuring the cost of capital (Benzie, 1992; Ariff and Safari,

\footnotetext{
${ }^{4}$ To minimize the potential impact of outliers, the dependent variables and regressors were winsorized at the $1^{\text {st }}$ and $99^{\text {th }}$ percentiles.

${ }^{5}$ We first excluded Malaysian denominated bonds and sukuk, which are exchange-listed and issued in Malaysian ringgit. The motivation was that publicly available financial data (e.g., income statement and balance sheet data) is accessible through Bloomberg or annual company statements. Although some data had limited availability on Bloomberg, we extracted the data from the websites of the companies whose data was not updated on Bloomberg. Next, we limited the sample to fixed-coupon or zerocoupon bonds that are not callable, convertible, putable, or have sinking fund provisions. Likewise, guaranteed bonds and subordinated bonds/sukuk were excluded. It should be noted that the prices of guaranteed bonds reflect the credibility of the assurers rather than that of the company itself. Meanwhile, the prices of subordinated bonds vary by the priority precedence of the debt. As the yield spreads of bonds with less than one year to maturity are extremely sensitive, even to minor price changes (see Ericsson and Renault, 2006), these bonds were excluded. The final filter removed bond and sukuk issues of less than one year. Unlike sovereign bonds, which have greater liquidity, corporate bonds are traded less frequently. More reliable empirical results are likely from issues of longer duration (Shin and Kim, 2015). For example, a bond/sukuk issued at the beginning of 2005 and expiring at the end of 2008 was included in the sample, whereas a bond/sukuk issued in the middle of 2013 (and is still outstanding) was excluded. This filter helped us include bonds with more observation points, thus improving the reliability and statistical power of our data set.
} 
2012). It also considers the pattern of coupon payments, the bond's term to maturity, and the capital gain (or loss) over the remaining life of the bond. If we set the internal rate of return (IRR) for a set of cash flows to be the rate that applies from a start-date to an end-date, then we can assume the IRR to be the YTM for these cash flows. Hence, the YTM is equivalent to the IRR of the bond, i.e., the rate that equates the value of the discounted cash flows on the bond to its current price. This calculation assumes that the bond is held until maturity, and consequently, the cash flows to maturity are discounted in the calculation. Liu and Skully (2005) used yield spreads (rather than interest rates) as the risk measurement, as they help overcome the inflation that fluctuates and dynamically changes across industries. According to Saad et al. (2020), as the inflation rate is unpredictable and uncertain, it is prohibited by Muslim investors (Saad et al., 2020). Thus, the following equation is presented:

$$
Y T M=\frac{C+\frac{F-P}{n}}{\frac{F+P}{2}}
$$

where $C$ is the coupon/interest payment, $F$ is the face value, $P$ is the price, and $n$ is the years to maturity. Meanwhile, the spread is given as follows:

$$
\text { Spread }_{i, t}=Y T M_{i, t}-Y T M M G S_{i, t}
$$

where $i$ is the corporate bond/sukuk issued at time $t, Y T M_{i, t}$ is the yield to maturity of the corporate bond/sukuk, and YTMMGS $S_{i, t}$ is the yield to maturity of the MGSY of the comparable maturity.

\subsection{Explanatory Variables}

We divided the determinants (i.e., the independent variables) of the credit spreads into three groups: (1) firm-specific variables; (2) bond characteristics; and (3) macroeconomic variables. Table 3 provides a list of the variables with brief descriptions and the predicted signs.

In this study, the firm-specific variables included: return on assets (ROA), the capitalization ratio, the leverage ratio, the interest coverage ratio, size, and equity volatility. The profitability (ROA) of a firm was captured by the ratio of earnings before interest and taxes (EBIT) to assets. Balasubramanian and Cyree (2012) conjectured that higher ROA is only possible with higher risktaking, resulting in a higher cost of debt. Hence, the yield spread increases with ROA. Based on 
this finding, the variable shows a positive association, indicating that changes in the debt market signal variations in a firm's risk. Meanwhile, a firm's equity-to-total capitalization (Equity/ Capital) indicates the portion of its capital structure funded by equity. As for equity holders' risk, it inversely varies with equity-to-total capitalization.

As a firm's leverage ratio is a common distress proxy for explaining the leverage position of a firm, we employed a book value-based classification of firm leverage, defined as long-term debt divided by total assets (Debt/Assets). Additionally, interest coverage was defined by the EBIT to interest expense. This ratio measures a firm's capability to cover its interest payment on its outstanding debt. In this case, the lower the ratio, more the firm is burdened by the interest expense. Thus, as the credit spread increases, the coefficient of this ratio reports a negative association.

Next, we employed SIZE as a firm-specific variable to explain the bond spreads. In the present study, SIZE was the natural logarithm of the book value of a firm's total assets. Meanwhile, empirical findings elsewhere showed that variables, such as equity market risk factors, affect the credit spread (e.g., Collin-Dufresne et al., 2001; Campbell and Taksler, 2003). Hence, we incorporated the equity volatility of the issuing firm in our model to account for any changes in stock market dynamics that may affect the yield spread. In this regard, any increase in the volatility of a firm's value increases the probability of default, which, in turn, increases the credit spread (Collin-Dufresne et al., 2001). Additionally, equity volatility is the standard deviation of day-today logarithmic price changes. As our data included quarterly observations, the quarterly change in the most recent quarter's closing prices was expressed as a percentage. ${ }^{6}$

The bond characteristics variables in this study included time to maturity and the interaction term time-to-maturity * leverage. The rationale for including this variable is the presence of maturitysensitive clientele for corporate bonds (see Longstaff et al., 2005). Meanwhile, the risk of the default varies and depends on the bond's time to maturity and a firm's leverage, while the structure of the credit spreads vary with the leverage of the firm, indicating a strong dependence of the change in time to maturity on leverage. In order to control for this dependence in the simplest way, we included the interaction term time-to-maturity * leverage in the linearized estimating equation,

\footnotetext{
${ }^{6}$ Based on the daily equity price data, quarterly annualized equity volatility was calculated as [Quarterly std. dev $\{$ ln $(\mathrm{Pt} / \mathrm{Pt}-$ 1) $\}] *[\operatorname{sqrt}(4)]$.
} 
along with time to maturity. In this case, if there are two bonds with the same maturities but different leverage levels, then the bonds with the low leverage levels will result in lower spreads, whereas the bonds with high leverage levels will result in higher spreads.

As for the macroeconomic variables in this study included: the industrial production index (IPI), the consumer price index (CPI), the gross domestic product (GDP) growth rate, and slope (10- and 2-year). The IPI captures the effects of economic conditions on yield spreads, and it is an indicator of the actual production output of businesses integrated into the industrial sector of the economy. For instance, the rate of change in the IPI is negatively related to yield spreads if a rise in economic activity boosts investors' confidence, thus leading to a reduction in the risk premia. Meanwhile, the CPI (as a proxy for inflation) is relevant because of its influence on the risk-free rate and the discount rate agents use to price assets (Amato and Luisi, 2006). According to David (2008), inflation risk compromises the purchasing power of future cash flows. Hence, the higher the inflation rate, higher the yield spread.

Moreover, the GDP is a proxy for economic growth. In an economic downturn, a firm's capacity to meet payment obligations significantly weakens. Based on previous research (e.g., Stock and Watson, 1989; Estrella and Mishkin, 1998), a steepening term structure (i.e., lower short-term interest rates and/or higher long-term rates) portents future growth. Therefore, to measure the slope of the yield curve, we calculated the difference between 10- and 2-year Malaysian government yields.

\section{[Insert Table 3 here]}

Finally, Tables 4 and 5 present the pairwise correlation among the independent variables for conventional bonds and sukuk, respectively. Based on the findings, there was no indication of multicollinearity (see the correlation matrix in these tables).

[Insert Tables 4 and 5 here] 


\section{Methodology}

\subsection{Model}

In this study, the data enabled us to observe both time-series and cross-sectional variations in the credit spread determinants. ${ }^{7}$ Our analysis also referred to the yield spreads of conventional corporate bonds and sukuk in 3-, 5-, 7-, and 10-year maturities issued by Malaysian firms from 2002 to 2013. Based on the variable descriptions in the previous section, the baseline specification of our model is as follows:

$\ln \left(\right.$ Sukuk/Bond Spread $\left._{i f t}\right)=\beta_{0}+\beta_{1}$ Firm $_{i t}+\beta_{2}$ Sukuk $_{i t} /$ Bond $_{i t}+\beta_{3}$ Macro $_{t}+\beta_{4}$ Sector $_{i t}+$

$$
\mathbf{A}_{\mathbf{f}}+\mathbf{B}_{\mathbf{t}}+\mu_{i f t}
$$

where ln $\left(\right.$ Sukuk/Bond Spread $\left._{\text {ift }}\right)$ is the natural logarithm of the difference between the yield at the issuance of $S_{u k u k_{i}} /$ Bond $_{i}$ of firm $f$ at issuance date $t$ and the yield of a government bond with comparable maturity. Meanwhile, Firmit is the vector of the firm-level determinants of the corporate yield spreads; Sukuk $k_{i} /$ Bond $_{i t}$ represents the bond-structure characteristics; Macrot $_{t}$ refers

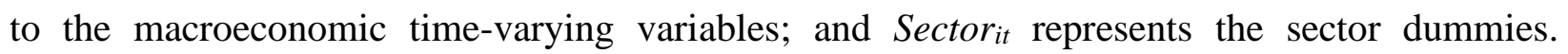
Moreover, $\mathbf{A}_{\mathbf{f}}$ and $\mathbf{B}_{\mathbf{t}}$ are the vectors of the firm- and quarterly-time dummy variables that account for firm- and time-fixed effects, while $\mu_{i f t}$ is the error term.

\subsection{Model Selection and Specification}

In the present study, a likelihood-ratio test between the ordinary least squares (OLS) regression and the fixed effect model (FEM) was conducted to determine if it is inappropriate to run a simple OLS model. ${ }^{8}$ Further, the Breusch-Pagan Lagrange multiplier test for random effects was used to determine whether the OLS regression is a better fit than the random effects (REM) model. ${ }^{9}$

\footnotetext{
${ }^{7}$ Murray (2006) referred to data that contains a time series of cross-sections as "panel data." In the presence of firm- and time-fixed effects, the pooled OLS estimation can produce biased results. Thus, we applied a panel data regression framework.

${ }^{8} \mathrm{We}$ also conducted a poolability test, in which we compared the OLS model (with restricted parameters) and the FEM (with unrestricted parameters) to determine whether adding fixed and time effects to the model significantly improves the model fit. The likelihood ratio test statistics were significant and failed to reject the FEM as the best-fit model.

${ }^{9}$ Murray (2006) pointed out that panel data with unobserved heterogeneity comes in two varieties. The unobserved heterogeneity may be the same from one sample to the next or it may randomly vary from one sample to the next. FEMs are suitable when the unobserved differences among groups are the same from one sample to the next. Error component models (random error models) are those, in which the unobserved differences among groups randomly vary from one sample to the next.
} 
Meanwhile, the Hausman test suggested that the FEM is a better fit. ${ }^{10}$ Thus, we used the FEM with Driscoll and Kraay's (1998) standard errors (FEM-DR) to control for heteroscedasticity, autocorrelation, and possible correlation among the groups in the panel data. It should be noted that Driscoll and Kraay (1998) adapted the Newey-West estimator in the panel time-series context, in which not only the serial correlation between residuals from the same individual observations in different times was considered but the cross-serial correlation between the different individual observations in different times was also considered (see also Arellano, 2003).

In this study, the FEM estimator was implemented in two steps. ${ }^{11}$ In the first step, the model variables $z_{i t} \in\left\{y_{i t}, \boldsymbol{x}_{i t}\right\}$ were within-transformed as follows:

$\tilde{z}_{i t}=z_{i t}-\bar{z}_{i}+\overline{\bar{z}}$, where $\quad \bar{z}_{i}=T_{i}^{-1} \sum_{t=t_{i 1}}^{T_{i}} z_{i t} \quad$ and $\quad \overline{\bar{z}}=\left(\sum T_{i}\right)^{-1} \sum_{i} \sum_{t} z_{i t}$

We also recognized that the within-estimator corresponds to the OLS estimator as follows:

$\tilde{y}_{i t}=\tilde{x}_{i t}^{\prime} \theta+\tilde{\varepsilon}_{i t}$

In the second step, we estimated the transformed regression model in the aforementioned equation by pooled OLS estimation, with Driscoll and Kraay's (1998) standard errors.

\subsection{Variance Decomposition}

In order to examine the bond/sukuk spreads, we quantified the relative contributions of the three groups of determinants: (1) firm-specific variables, (2) bond characteristics, and (3) macroeconomic variables. Then, we performed a variance decomposition ${ }^{12}$ exercise, based on the regressions in Columns (1) and (5) of Table 7 for the bonds and sukuk, respectively. Finally, we

\footnotetext{
10 The model was also estimated by assuming the homoscedasticity of the residuals. Within the series of additional tests, the Woolridge test of cross-sectional dependence showed that the residuals across entities were correlated, while the modified Wald test for heteroscedasticity rejected the null of constant variance in the residuals. Although these tables were omitted to maintain brevity, they can be presented upon request.

${ }^{11}$ In Stata, the $x t s c c$ program's option fe estimates FEM (within) regression, with Driscoll and Kraay's (1998) standard errors.

${ }^{12}$ We employed a user-developed Stata module named rego, which decomposes the R2 (i.e., the share of explained variance) of linear regression into contributions of (or groups of) regressor variables, with the help of Shapley or Owen values. As for the "groups" of variables that belong to the same category (such as the variables that belong to a polynomial in age), the computational effort is lower than in the "classical" Shapley decomposition without groupings. Meanwhile, rego includes an implemented option to bootstrap the decomposition results in order to obtain percentile confidence.
} 
performed a variance decomposition analysis to quantify the importance of each set of determinants to explain the variations in the bond/sukuk spreads.

\section{Results and Discussion}

\subsection{Descriptive Statistics}

Table 6a presents the summary statistics of the dependent variable yield spreads of the conventional bonds and sukuk in the Malaysian government securities. On average, the sukuk yields spread across the four segments (3-, 5-, 7-, and 10-year maturity) varied between 1.7 basis points (bp) and $3.5 \mathrm{bp}$, whereas the conventional bonds' yield spreads mostly varied between 1.4 bp and $1.9 \mathrm{bp}$.

Table $6 \mathrm{~b}$ includes the summary statistics of the variables used in the analysis. The determinant variables used in the conventional bonds' sample and that of sukuk did not significantly differ. With the exception of the capitalization ratio (e.g., .55 for conventional bonds and .60 for sukuk) and size (e.g., 35,214.67 million MYR for conventional bonds and 20,925.1 million MYR for sukuk), there was a minimal difference in the average values of the variables used to analyze the credit spread determinants for conventional bonds and sukuk. ${ }^{13}$

It should be noted that unlike developed market firms, which include average leverage ratios ranging from $40 \%$ to $90 \%$ (Arellano, 2008), Malaysian market firms display low leverage ratios (e.g., 29\% and $27 \%$ for firms issuing conventional bonds and sukuk, respectively). This may be attributed to the generalized constraints faced by the firms in emerging and developing financial markets.

\section{[Insert Tables 6(a) and 6(b) here]}

\subsection{Empirical Results}

We estimated Equation (1) for the full sample of Malaysian corporate bonds (2,298 observations) and sukuk (929 observations) from 2002 to 2013 by using four alternative estimators: (1) OLS, (2)

\footnotetext{
${ }^{13}$ Based on a thorough comparison of the descriptive statistics of both sukuk and conventional bonds, we found that the spreads of the overall sample and for the different maturities were comparable, with the exception of the conventional bonds with 10-year maturity. A further inspection showed that the frequency of the conventional bonds with 10-year maturity was 45 out the 2,238 observations, which is equivalent to $2 \%$ of the total conventional bond sample. Meanwhile, the frequency of 10 -year sukuk was 116 out of 972 , which is equivalent to $12 \%$ of the total sukuk sample. We attributed the difference in the spreads between the two types of bonds to the lack of sample/frequency of the conventional bonds.
} 
REM, (3) FEM, and (4) FEM-DR. The results of these equations for both conventional bonds and sukuk are presented in Table 7. Next, we created various sub-samples based on the maturities of the conventional bonds and sukuk (see Tables 8 to 11). The motivation was to determine if the empirical results continued to hold within the sub-samples.

\subsubsection{The Determinants of Credit Spreads (Full Sample)}

According to Table 7, which presents the results of the full sample of bonds and sukuk, many coefficients refute our prior expectations. For example, whereas the coefficient related to firm profitability (EBIT/Assets) for sukuk was significant and negative but for conventional bonds was positive and insignificant.

Contrary to the theoretical predictions and conventional wisdom, and in line with Balasubramanian and Cyree (2012), the positive associations for conventional bonds highlight that higher ROA for conventional bonds is the outcome of high risk-taking and is consistent with expectation that a trade-off between risk and return exists. Thus, yield spread increases with ROA and results in a higher cost of debt. With reference to the statistical insignificance of this variable, it is evident from the variance decomposition analysis (discussed later) that ROA explains just under 5\% of the variation in the credit spreads of both sukuk and conventional bonds.

Regarding the coefficient of the capitalization ratio (Equity/Capital), it was only significant for conventional bonds, as the coefficient for bonds was positive and that for sukuk was negative. ${ }^{14}$ For the sub-samples (varying maturities), we observed positive associations, with the exception of sukuk with 5-year maturity, indicating the overall sukuk benefit from higher capitalization ratios. This also implies that firms in Malaysia that issue 5-year maturity sukuk could benefit from debt financing, which can subsequently provide them with a tax shield and lower spreads.

As for the coefficients of the proxy for firm leverage (Debt/Assets), they were negative for both sukuk and conventional bonds. However, these results were not in line with our expectations. Meanwhile, the interest coverage ratio was used as a proxy for estimating a firm's debt-servicing

\footnotetext{
${ }^{14}$ Intuitively, higher ratios of equity over capital make the bond-/sukuk-issuing firm less risky, resulting in a negative point estimate for the capitalization ratio. This intuition holds true for conventional bond spreads, as the coefficient is negative. However, for sukuk spreads, the coefficient of the capitalization ratio was positive and significant, implying that higher capitalization firms issuing sukuk may have higher yields, which result in a larger credit spread.
} 
ability. In this regard, a higher value indicates better financial health, which, in turn, implies a lower spread. Additionally, the coefficients for sukuk showed a negative association, while there was a positive association for conventional bonds. However, none of them were significant, implying that this debt-servicing determinant does not explain the credit spread. These findings were also confirmed through the variance decomposition results (see Figure 2).

The coefficient estimates of asset size were negative for the spread of both the sukuk and conventional bonds. This result was in line with our expectation as discussed in Section 4.3. In addition, the equity volatility (a proxy for idiosyncratic risk) coefficient was positive for both sukuk and conventional bonds. However, it was only statistically significant in the case of conventional bonds. This positive estimate also confirmed that higher levels of volatility lead to higher yields, thus resulting in higher spreads. As for sukuk, the effects of all firm-specific variables, except for the capitalization ratio, were in line with our prior assumption that leads to lower spreads. Thus, we failed to reject $H_{01}$, rendering sukuk less risky.

Concerning the signs of the coefficients for both years to maturity and years to maturity * debt to assets, they were not in line with our expectation. However, both bond-specific variables were significant for sukuk as well as for conventional bonds. The negative coefficient of years to maturity for the two types of securities was also counterintuitive. Yet, this effect could be somewhat mitigated at higher levels of debt, in which more time reduces the risk and the spreads. Consequently, a negative association was observed for these two security types.

Moreover, the interaction term for both sukuk and conventional bonds indicated a positive coefficient, which was contrary to the predicted direction of the association and the economic insights. In this regard, higher financially leveraged firms with less time remaining to maturity show low yields and spreads. As for the validity of $H_{02}$, it was important to analyze both securities according to their maturity. Consequently, we observed that firms with high leverage do not benefit from issuing either long-term bonds or sukuk. This finding is similar with that of Chen et al. (2020), in which the long-term maturity effect on credit spreads is positive for firms with high leverage or high systematic risk.

Furthermore, the effect of the macro factors on the spreads for both types of securities differed, while the coefficients of several macro variables were mainly in line with our prior expectation. 
Meanwhile, the signs of the coefficients for IPI, for both conventional bonds and sukuk, were not in line with our prior expectation and not statistically significant, as evident from the variance decomposition graph (discussed later). For sukuk, an interesting observation was the positive effect of the slope on the credit spreads, which was in contrast to previous studies such as Duffie et al. (1999). However, these positive relationships were similar to the findings of Yap and Gannon (2007), who analyzed the factors affecting the credit spread behavior of USD Malaysian bonds. They also cited that liquidity shortage was associated with the positive coefficients of slope. Thus, $\boldsymbol{H}_{03}$ does not entirely hold true when considering the full sample.

Finally, we observed that for sukuk, firm-specific variables, such as size, profitability, and the interest coverage ratio, showed negative associations, indicating lower spreads for sukuk. As opposed to the spreads of the conventional bonds, sukuk spreads do not widen due to equity volatility. This implies that sukuk are less risky than conventional bonds. Our sample also had lesser long-term maturity sukuk, suggesting that short- and medium-term sukuk have lower spreads. This finding was confirmed when the coefficient of time to maturity was positive, indicating that sukuk spreads widen (see Section 6.2.2.d).

\subsubsection{Determinants of the Credit Spreads by Maturities}

\section{a. 3-year Maturity}

Table 8 presents the estimates for conventional bonds and sukuk with a 3-year maturity. For firmspecific variables, the majority of the regression results were not that different from the baseline results (see Table 7) of the full sample.

The profitability coefficient (EBIT/Assets) for sukuk and bonds followed those of the baseline results. The coefficient of ROA for sukuk was also in line with our prior expectation (i.e., higher returns are associated with higher profitability). For the bonds, ROA again showed increased spreads. Next, the capitalization coefficients for conventional bonds and sukuk were in line with our theoretical expected results. However, the sign for the coefficient of the capitalization under sukuk differed from the baseline results (i.e., higher capitalization of the firms issuing short-term sukuk is associated with reduced risk premia). 
Additionally, the interaction term years to maturity * debt to assets for both sukuk and bonds was significant and was in line with the baseline results, indicating that the shorter the time to maturity, higher the risk. The interaction term also suggested that with a higher leverage, the probability of curtailing risks lowers, thus increasing the spreads and raising the yields.

The behavior of the macroeconomic factors for securities with a 3-year maturity also closely followed the baseline results. For example, for conventional bonds, the slope coefficient was positive and similar to that of the full sukuk sample (see Table 7). This implies that the issue of liquidity shortage might be evident for both short-term sukuk and conventional bonds in the Malaysian bond market, resulting in higher credit spreads when the slope is steep. Moreover, when we compared both types of securities with a 3-year maturity, except for $\triangle C P I$ and GDP growth, the coefficients for conventional bonds and sukuk included the same direction of the predicted association. These findings primarily support $\boldsymbol{H}_{03}$ and are consistent with our predictions.

\section{b. 5-year Maturity}

Table 9 presents the estimates for conventional bonds and sukuk with a 5-year maturity. For firmspecific and bond-/sukuk-specific variables, all the results were in line with the baseline results of the full sample, except for sukuk's ROA coefficient.

However, the regression results for the macroeconomic factors of sukuk differed from those of conventional bonds. Thus, we failed to accept $\boldsymbol{H}_{03}$. We also observed that the coefficient of growth change (CPI and GDP) did not follow our prior expectations. This can be attributed to the fact that investors' expectations regarding inflation and GDP growth can differ, depending on the state in which the economy is operating. For instance, an unexpected hike in the interest rate increases market participants' inflation expectations during good times but not during bad times. This indicates that the sukuk market participants (i.e., the holders of medium-term maturity sukuk) perceive inflation expectations to be positive during good times and negative during bad times. Hence, credit spreads narrow (widen) following an unexpected increase (decrease) in the CPI, which might be perceived by the market participants as positive (negative) news about the future of the economy during good times. 


\section{c. 7-year Maturity}

Table 10 identifies the effects of firm-specific, bond-/sukuk-specific, and macroeconomic factors on the credit spreads of bonds/sukuk with a 7-year maturity. With the exception of the capitalization and interest coverage ratios, the coefficients of sukuk across all the categories were in line with the baseline results. In the case of conventional bonds, with the exception of the capitalization and size coefficients, all the firm-specific coefficients were in line with the baseline results. These findings do not support $\boldsymbol{H}_{01}$. In the case of bonds/sukuk with a 7-year maturity, the regression results for all the macroeconomic variables of both types of securities differed. Thus, we failed to accept $\boldsymbol{H}_{\mathbf{0 3}}$.

\section{d. 10-year Maturity}

Table 11 presents the regression results for bonds/sukuk with a 10-year maturity. The direction of the associations for the coefficients of the variables under the conventional bonds was in line with our expectations, except for leverage and GDP growth. However, in the case of sukuk, there were a few deviations. Specifically, deviations were found in the interest coverage ratio, the interaction term, and two macro factors, namely, $\triangle I P I$ and $\triangle C P I$. It should be noted that this was the only table that closely matched our prior expectations regarding firm-specific and bond-specific variables, indicating that longer securities behave in a similar manner to bonds issued globally. Thus, our findings support $\boldsymbol{H}_{01}$ to $\boldsymbol{H}_{03}$.

\subsubsection{Variance Decomposition}

Overall, firm-specific, security-specific characteristics, and macroeconomic conditions were relevant to bond/sukuk spreads in Malaysia. Based on the regression results in Table 7, a variance decomposition exercise, represented in a comparative chart (see Figure 2), illustrates the idiosyncratic impact of the factors on sukuk and conventional bonds. For sukuk, firm-specific factors accounted for approximately $54 \%$ of the total variance, compared with roughly $48 \%$ for conventional bonds. Next, as indicators, size, leverage, and capitalization were respectively associated with $34 \%, 8 \%$, and $7.8 \%$ of the total variance for sukuk spreads, while for conventional bonds, volatility, leverage, and size were respectively associated with $14.2 \%, 14 \%$, and $8.9 \%$ of the total variance of bond spreads. We also observed that bond-/sukuk-specific factors (time to maturity and time to maturity * debt/assets) were associated with approximately $40 \%$ of the total 
variance for both sukuk and bonds. Whereas the interaction term time to maturity * debt/assets was associated with less than $1 \%$ of the variance in the case of sukuk spreads, the corresponding value for bonds was $26 \%$. Further, we found that macroeconomic conditions were associated with less than $7 \%$ of the variance in sukuk spreads, while the corresponding value for bonds was $12 \%$.

\subsection{Sensitivity Analysis and Robustness Checks}

In order to determine whether our results were adversely affected by any endogeneity of the firmspecific variables, we considered the two-step generalized method of moments (GMM) estimator of Cavallo and Valenzuela (2010). ${ }^{15}$ Using this estimator, we tested firm-specific variables with 1- and 2-year lags. ${ }^{16}$ The unreported results derived from these estimations were robust and consistent across the alternative specifications. ${ }^{17}$ Hence, the baseline results did not appear to be driven by endogeneity bias. ${ }^{18}$

We also examined the impact of the ownership of the issuing company on yield spreads (see Table 12). For instance, we assessed if a domestic or a foreign company issued a bond/sukuk and if it helped explain the yield spread for both types of securities. In this case, we considered conventional bonds and sukuk with a 5-year maturity, as this maturity class included the highest number of observations. We found that for domestic firms that issued corporate bonds, they had a negative impact on bond spreads. This finding is in line with that of Campbell and Taksler (2003). Meanwhile, bonds and sukuk issued by foreign companies had little to no effect on bond spreads.

We further identified the differences in the yield spread determinants, if we were only to include non-financial companies in the full sample (see Table 13). The overall results were in line with our predictions for both sukuk and conventional bonds. Moreover, we noted the following. First, an increase in interest coverage lowered the spread. Second, taking into consideration all the sectors, a decrease in slope lead to an increased spread. However, the opposite was observed if we

\footnotetext{
${ }^{15}$ We implemented a two-step GMM approach (using the Stata command ivreg2), which is in line with Cavallo and Valenzuela (2010). More information on GMM can be found in Arellano and Bover (1995).

${ }^{16}$ As we used quarterly data, this implies that we tested each variable $t$ with lags $t-4$ and $t-8$. The GMM estimations also included the results from the Sargan test of over-identifying restrictions. The joint null hypothesis of this test is that the instruments are uncorrelated with the error term and that the excluded instruments are correctly excluded from the estimated equation.

${ }^{17}$ The unreported results derived from these estimations were largely unchanged from the baseline regressions. The tables can be presented upon request.

${ }^{18}$ We also considered the effect of financial crises by observing the period from 2007 to 2010 (as the crisis period) and assigning dummy variables. We found no significant change or deviations from our baseline results.
} 
excluded the financial companies (i.e., an increase in slope lead to a decrease in spread). Third, for sukuk, after excluding the financial institutions, both the firm-level and bond-/sukuk-specific variables were affected. We also found that after excluding the financial firms, the ROA and CAP (the two firm-level determinants) showed an increase in spread. This was an opposite result to the main findings (i.e., when these variables reported a decrease in the credit spread). Additionally, an increase in spread due to an increase in ROA for non-financial firms issuing sukuk suggested that these firms conducted high risk-taking activities, resulting in a higher spread. The positive coefficient on the capitalization ratio for non-financial firms issuing sukuk also showed that as opposed to the sukuk data with financial firms, the non-financial firms followed a different capital structure, such that the higher ratios of equity over capital made the bond-/sukuk-issuing firms riskier, resulting in a positive point estimate for the capitalization ratio. Fourth, after excluding the financial institutions, the sukuk-specific factors also affected the spread differently than the pooled sample. In other words, as the leverage level was low for a non-financial company, the longer the maturity of sukuk, the lower the spread.

Finally, another sensitivity analysis was conducted (see Table 14) by running the model on the full sample. In this case, the objective was to compare the results of the firms issuing both corporate bonds and sukuk with those only issuing corporate bonds. Among the total sample of 58 companies, 33 companies issued both sukuk and conventional/corporate bonds, while 25 companies only issued corporate bonds. A negligible difference was found between this model and the baseline model in Table 7.

\section{Conclusion}

This study identified the relevant factors for determining the yield spreads of sukuk and conventional bonds. In this regard, understanding the causes of different risk premiums is important to investors, issuers, and regulators. Although still in their nascent stage, sukuk markets are a growing impetus in emerging economies, where sukuk is conducive to raising capital for infrastructure projects and where investors tend to hold assets to maturity. Thus, we utilized a comprehensive set of measures representing firm-specific and industry-specific variables, bond characteristics, and macroeconomic conditions for a sample of listed firms in Malaysia. 
Based on the findings, sukuk are generally less risky than conventional bonds (Abdelsalam et al., 2020) and that firm-specific indicators are the primary determinants. According to the variance decomposition analysis, size, capitalization, and leverage were significantly and negatively associated, indicating lower spreads for sukuk. In contrast to the spreads of conventional bonds, sukuk spreads did not widen due to equity volatility. This suggests that sukuk are less risky than conventional bonds. Meanwhile, the cross-sectional regression of firm-specific determinants explained $51 \%$ of the variance in sukuk spreads. For conventional bonds, the variance decomposition analysis showed that only leverage and volatility are significant, as the firm-level indicators and cross-sectional regression of the firm-specific determinants explained $41 \%$ of variance in sukuk spreads. Regarding the bond-specific characteristics, time to maturity and the interaction of the debt with the remaining time to maturity was significant. This implies that sukuk investors tend to hold sukuk until maturity and that Malaysian firms with high leverage do not benefit from long-maturity bonds and sukuk.

For both sukuk and conventional bonds, our sub-sample results indicated that spreads can vary with maturity, while the significant macroeconomic factor was the difference between 10- and 2year Malaysian government yields. This difference was most likely due to the weak integration between Association of Southeast Asian Nations (ASEAN) bond markets, as previously observed (see Plummer and Click, 2005; Tsukuda et al., 2017).

Overall, this study offers important insights and policy implications to investors, regulators, and other stakeholders engaging with different bond markets. As for policymakers, they must be aware of the systematic risks, which can be a deterrent to investment. Various factors, such as time to maturity and the interaction terms leverage and time to maturity, are equally important to sukuk and corporate bonds investors in that they do not benefit from long-term maturity bonds and sukuk. Our study also includes wide implications for conventional bond markets, where the emergence of a new asset class can boost investments across various market segments. In terms of high volatility and low interest rates, the availability of sukuk as an alternative asset option can facilitate economic growth.

Moreover, a number of possibilities exist for future research. In particular, future studies should examine the differences between sukuk and bond markets for different regions. They should also conduct a duration and convexity analysis to identify additional factors related to risk premiums. 
In these cases, the overall objective should be to facilitate the development of Islamic capital markets in order to attract investors to hold sukuk, while moving beyond faith-based motives.

\section{Acknowledgements}

The co-authors would like to thank the editor, the three anonymous referees and the Copy-Editor for their valuable comments and directions, which have greatly improved the overall exposition of this study. We are also grateful to the participants of the $4^{\text {th }}$ International Conference on Applied Theory, Macro, and Empirical Finance (AMEF) in Thessaloniki, Greece, for their valuable comments. Special thanks to Gerald Steele for his comments and suggestions.

\section{References}

1. Accounting and Auditing Organization for Islamic Financial Institutions (AAOIFI), 2008. Resolutions on Sukuk, Shari'a Board of AAOIFI. Manama, Bahrain: AAOIFI.

2. Abdelsalam, O., Elnahass, M., Ahmed, H., Williams, J., 2020. Asset securitizations and bank stability: Evidence from different banking systems. Global Finance Journal. Doi: https://doi.org/10.1016/j.gfj.2020.100551

3. Akhtar, S., Akhtar, F., Jahromi, M., John, K., 2017. Impact of interest rate surprises on Islamic and conventional stocks and bonds. Journal of International Money and Finance. 79, 218-231.

4. Aloui, C., Hammoudeh, S., Hamida, H., 2015a. Co-movement between sharia stocks and sukuk in the GCC markets: A time-frequency analysis. Journal of International Financial Markets, Institutions and Money. 34(C), 69-79.

5. Aloui, C., Hammoudeh, S., Hamida, H., 2015b. Global factors driving structural changes in the comovement between sharia stocks and sukuk in the Gulf Cooperation Council countries. The North American Journal of Economics and Finance. 31(C), 311-329.

6. Amato, J., Luisi, M., 2006. Macro factors in the term structure of credit spreads. BIS Working Paper No. 203. Available at SSRN: https://papers.ssrn.com/sol3/papers.cfm?abstract_id=637481 (Accessed: 15/03/2020).

7. Amrani, M. B., Hamza, F., Mostapha, E. H., 2017. Sukuk: Literature review. Social and Administrative Sciences. 4(1), 124-131.

8. Arellano, C., 2008. Default risk and income fluctuations in emerging economies. American Economic Review. 98(3). 690-712.

9. Arellano, M., 2003. Panel data econometrics. Oxford, Oxford University Press.

10. Arellano, M., Bover, O., 1995. Another look at the instrumental variable estimation of errorcomponents models. Journal of Econometrics. 68(1), 29-51.

11. Ariff, M., Safari, M., 2012. Are sukuk securities the same as conventional bonds? Afro Eurasian Studies. 1(1), 101-125.

12. Azmat, S., Skully, M., Brown, K., 2014. Credit risk in Islamic joint venture bond. Journal of Economic Behavior and Organization. 103, S129-S145.

13. Balasubramanian, B., Cyree, K.B., 2011. Market discipline of banks: Why are yield spreads on bankissued subordinated notes and debentures not sensitive to bank risks? Journal of Banking \& Finance. 35(1), 21-35. 
14. Benzie, R., 1992. The development of the international bond market. BIS Economic Papers no. 32, 196.

15. Cakir, S., Raei, F., 2007. Sukuk vs. Eurobonds: Is there a difference in value-at-risk? IMF Working Paper No. 07/237. IMF, Washington DC.

16. Campbell, J. Y., Taksler, G.B., 2003. Equity volatility and corporate bond yields. Journal of Finance. 58(6), 2321-2350.

17. Cavallo, E.A., Valenzuela, P., 2010. The determinants of corporate risk in emerging markets: An option-adjusted spread analysis. International Journal of Finance and Economics. 15(1), 59-74.

18. Chen, H., Xu, Y., Yang, J., 2020. Systematic risk, debt maturity and the term structure of credit spreads. Journal of Financial Economics. 139(3), 770-779.

19. Chen, L., Lesmond, D. A., Wei, J., 2007. Corporate yield spreads and bond liquidity. Journal of Finance. 62(1), 119-49.

20. Collin-Dufresne, P., Goldstein, R.S., Martin, J.S., 2001. The determinants of credit spread changes. Journal of Finance. 56(6), 2177-2207.

21. David, A., 2008. Inflation Uncertainty, Asset valuations, and the credit spreads puzzle. The Review of Financial Studies. 21(6), 2487-2534.

22. Driscoll, J., Kraay, A., 1998. Consistent covariance matrix estimation with spatially dependent panel data. Review of Economics and Statistics. 80(4), 549-560.

23. Duffie, D., Singleton, K.J., 1999. Modelling the term structure of default able bonds. The Review of Financial Studies. 12(4), 687-720.

24. Duffie, D., Saita, L., Wang., K., 2007. Multi-period corporate failure prediction with stochastic covariates. Journal of Financial Economics. 83(3), 635-665.

25. Ericsson, J., Renault, O., 2006. Liquidity and credit risk. Journal of Finance. 61(5), 2219-2250.

26. Elton, E.J., Gruber, M., Agrawal, D., Mann, C., 2001. Explaining the rate spread on corporate bonds. Journal of Finance. 56(1), 247-277.

27. Estrella, A., Mishkin, F.S., 1998. Predicting U.S. recessions: Financial variables as leading indicators. Review of Economics and Statistics. 80(1), 45-61.

28. Fama, E., French, K., 1993. Common risk factors in the returns on stocks and bonds. Journal of Financial Economics. 33(1), 3-56.

29. Flannery, M.J., Nikolova, S., Öztekin, Ö., 2012. Leverage expectations and bond credit spreads. Journal of Financial and Quantitative Analysis. 47(4), 689-714.

30.Gebka, B., Wohar, M.E., 2018. The predictive power of the yield spread for future economic expansions: Evidence from a new approach. Economic Modelling. 75(C),181-195.

31. Godlewski, C.J., Turk-Ariss, R., Weill, L., 2013. Do markets perceive sukuk and conventional bonds as different financing instruments? Journal of Comparative Economics. 41(3), 745-761.

32. Hanifa, M.H., Masih, M., Bacha, O., 2014. Sukuk and conventional bond offers based on corporate financing theories using partial adjustment models: Evidence from Malaysian listed firms. MPRA Paper 56953, University Library of Munich, Germany. Available at: https://mpra.ub.unimuenchen.de/56953/ [accessed on 01/01/2021].

33. Hassan, M., Paltrinieri, A., Dreassi, A., Miani, S., Sclip, A., 2018. The determinants of co-movement dynamics between sukuk and conventional bonds. The Quarterly Review of Economics and Finance. $68,73-84$.

34. Hayat, U., 2010. Islamic finance's sukuk explained. Financial Times, April 11. 
35. ICD Thomson Reuters (2015), ICD-Thomson Reuters Islamic finance development report 2016, Thomson Reuters, December 2015.

36. Jamaldeen, F., 2012. Islamic Finance for Dummies. John Wiley \& Sons, Hoboken, NJ.

37. Jarrow, R., Turnbull, S., 1995. Pricing derivatives on financial securities subject to credit risk. Journal of Finance. 50(1), 53-86.

38. Jobst, A., 2007. The economics of Islamic finance and securitization. IMF Working Paper 07/117. IMF, Washington DC.

39. Jobst, A., Peter, K., Paul, M., Sy, A., 2008. Islamic bond issuance what sovereign debt managers need to know. IMF Policy Discussion Paper 08/3. IMF, Washington DC.

40. Kagraoka, Y., 2010. A time-varying common risk factor affecting corporate yield spreads. European Journal of Finance. 16(6), 527-539.

41. Kenourgios, D., Naifar, N., Dimitriou, D., 2016. Islamic financial markets and global crises: Contagion or decoupling? Economic Modelling. 57, 36-46.

42. Krishnan, C.N.V., Ritchken, P.H., Thomson, J.B., 2010. Predicting credit spreads. Journal of Financial Intermediation. 19(4), 529-563.

43. Liu, B., Skully, M.T., 2005.The determinants of mortgage yield spread differentials: Securitization. Journal of Multinational Financial Management. 15(4-5), 314-333.

44. Liu, S., Shi, J., Wang, J., Wu, C., 2009. The determinants of corporate bond yields. The Quarterly Review of Economics and Finance. 49(1), 85-109.

45. Loncarski, I., Szilagyi, P.G., 2012. Empirical analysis of credit spread changes of US corporate bonds. International Review of Financial Analysis. 24, 12-19.

46. Longstaff, F.A., Schwartz, E.S., 1995. A simple approach to valuing risky fixed and floating rate debt. Journal of Finance. 50(3), 789-819.

47. Longstaff, F.A., Mithal, S., Neis, E., 2005. Corporate yield spreads: Default risk or liquidity? New evidence from the credit default swap market. The Journal of Finance. 60(5), 2213-2253.

48. Maghyereh, A.I., Awartani, B., 2016. Dynamic transmissions between Sukuk and bond markets. Research in International Business and Finance. 38, 246-261.

49. Murray, M.P., 2006. Avoiding invalid instruments and coping with weak instruments. Journal of Economic Perspectives. 20(4), 111-32.

50. Naifar, N., Hammoudeh, S., 2016. Dependence structure between sukuk (Islamic bonds) and stock market conditions: An empirical analysis with Archimedean copulas. Journal of International Financial Markets, Institutions and Money. 4, 148-165.

51. Paltrinieri, A., Hassan, M., Bahoo, S., Khan, A., 2019. A Bibliometric review on sukuk literature. International Review of Economics and Finance. 69, 389-405.

52. Peter, M., Grandes, M., 2005. How important is sovereign risk in determining corporate default premia? The Case of South Africa. IMF Working Paper No. 04/217. IMF, Washington DC.

53. Plummer, M.G., Click, R.W., 2005. Bond market development and integration in ASEAN. International Journal of Finance and Economics. 10(2), 133-142.

54. Ramasamy, R., Munisamy, S., Helmi, M.H.M., 2011. Relative risk of Islamic sukuk over government and conventional bonds. Global Journal of Management and Business Research. 11(6), 4-12.

55. Saad, N.M., Haniff, M.N., Ali, N., 2020. Corporate governance mechanisms with conventional bonds and Sukuk' yield spreads. Pacific-Basin Finance Journal. 62, 101116.

56. Safari, M., Ariff, M., 2014. Does market differentiate between Sukuk and bonds? Journal of Money, Investment and Banking. 29, 104-119.

57. Sclip, A., Dreassi, A., Miani, S., Paltrinieri, A., 2016. Dynamic correlations and volatility linkages between stocks and sukuk. Review of Financial Economics. 31, 34-44. 
58. Shin, D., Kim, B., 2015. Liquidity and credit risk before and after the global financial crisis: Evidence from the Korean corporate bond market. Pacific-Basin Finance Journal. 33, 38-61.

59. Stock, J.H., Watson, M.W., 1989. New indexes of coincident and leading indicators. NBER Macroeconomics Annual. 4, 351-409.

60. Tang, D.Y., Yan, H., 2006. Macroeconomic conditions, firm characteristics, and credit spreads. Journal of Financial Services Research. 29, 177-210.

61. Tsukuda, Y., Shimada, J., Miyakoshi, T., 2017. Bond market integration in East: Multivariate GARCH with dynamic conditional correlation approach. International Review of Economics \& Finance. 51, 13-213.

62. Wilson, R., 2008. Innovation in the structuring of Islamic sukuk securities. Humanomics. 24(3), 170181.

63. Yap, C.J., Gannon, G.L., 2007. Factors affecting the credit spreads behaviour of USD Malaysian bonds. Working Papers aef_2007_10, Deakin University, Department of Economics. Available at: https://ideas.repec.org/s/dkn/acctwp.html [accessed on 09/01/2021].

64. Valenzuela, P., 2016. Rollover risk and corporate bond spreads. Review of Finance. 20, 631-661.

65. Zulkhibri, M., 2015. A synthesis of theoretical and empirical research on sukuk. Borsa Istanbul Review. 15, 237-248. 


\begin{tabular}{|c|c|c|}
\hline & Sukuk & Conventional Debt \\
\hline Asset ownership & $\begin{array}{l}\text { Sukuk give the investor partial } \\
\text { ownership in the asset on which the } \\
\text { sukuk are based. }\end{array}$ & $\begin{array}{l}\text { Bonds do not give the investor a share of } \\
\text { ownership in the asset, project, business, or joint } \\
\text { venture they support. They are a debt obligation } \\
\text { from the issuer to the bond holder. }\end{array}$ \\
\hline Investment criteria & $\begin{array}{l}\text { The asset on which sukuk are based must } \\
\text { be Sharia-compliant. }\end{array}$ & $\begin{array}{l}\text { Generally, bonds can be used to finance any } \\
\text { asset, project, business, or joint venture that } \\
\text { complies with local legislation. }\end{array}$ \\
\hline Issue unit & $\begin{array}{l}\text { Each sukuk represents a share of the } \\
\text { underlying asset. }\end{array}$ & Each bond represents a share of debt. \\
\hline Issue price & $\begin{array}{l}\text { The face value of sukuk is based on the } \\
\text { market value of the underlying asset. }\end{array}$ & $\begin{array}{l}\text { The face value of a bond price is based on the } \\
\text { issuer's credit worthiness (including its rating). }\end{array}$ \\
\hline $\begin{array}{l}\text { Investment rewards } \\
\text { and risks }\end{array}$ & $\begin{array}{l}\text { Sukuk holders receive a share of profits } \\
\text { from the underlying asset (and accept a } \\
\text { share of any loss incurred). }\end{array}$ & $\begin{array}{l}\text { Bond holders receive regularly scheduled (and } \\
\text { often fixed rate) interest payments for the life of } \\
\text { the bond, and their principal is guaranteed to be } \\
\text { returned at the bond's maturity date. }\end{array}$ \\
\hline Effects of costs & $\begin{array}{l}\text { Sukuk holders are affected by costs } \\
\text { related to the underlying asset. Higher } \\
\text { costs may translate to lower investor } \\
\text { profits, and vice versa. }\end{array}$ & $\begin{array}{l}\text { Bond holders generally are not affected by costs } \\
\text { related to the asset, project, business, or joint } \\
\text { venture they support. The performance of the } \\
\text { underlying asset does not affect investor } \\
\text { rewards. }\end{array}$ \\
\hline
\end{tabular}

Source: Jamaldeen (2012: 211)

Table 1: The Differences between Sukuk and Conventional Debt 


\begin{tabular}{l|c|c|c|}
\hline Maturity & Sukuk & Conventional Bonds & Total \\
\hline 3-year & 19 & 34 & 53 \\
5-year & 31 & 78 & 109 \\
7-year & 6 & 17 & 23 \\
10-year & 6 & 15 & 21 \\
Total & $\mathbf{6 2}$ & $\mathbf{1 4 3}$ & $\mathbf{2 0 5}$ \\
\hline \hline
\end{tabular}

Table 2(a): Number of Bonds/Sukuk in the Sample According to Maturity

\begin{tabular}{l|c}
\hline \hline Sector & Companies \\
\hline Basic materials & 1 \\
Communications & 3 \\
Consumer & 17 \\
Diversified & 2 \\
Financial & 19 \\
Industrial & 15 \\
Utilities & 1 \\
Total & 58 \\
\hline \hline
\end{tabular}

Table 2(b): Companies According to Sectors 


\begin{tabular}{|c|c|c|c|c|}
\hline Variable & Definition & Unit of Measurement & Data Source & Expected Sign \\
\hline $\begin{array}{l}\text { Bond/sukuk } \\
\text { spread }\end{array}$ & YTM of sukuk- YTM of bond & $\begin{array}{l}\text { Percent (in natural } \\
\text { logarithms) }\end{array}$ & $\begin{array}{l}\text { Bloomberg/Data Stream/ } \\
\text { Author's calculation }\end{array}$ & \\
\hline Return on Assets & EBIT to assets & Percent & $\begin{array}{l}\text { Bursa Malaysia/Company's } \\
\text { Annual Accounts }\end{array}$ & - \\
\hline $\begin{array}{l}\text { Capitalization } \\
\text { Ratio }\end{array}$ & Equity/Capital & Percent & $\begin{array}{l}\text { Bursa Malaysia/Company's } \\
\text { Annual Accounts }\end{array}$ & - \\
\hline Leverage Ratio & Debt to assets & Percent & $\begin{array}{l}\text { Bursa Malaysia/Company's } \\
\text { Annual Accounts }\end{array}$ & + \\
\hline $\begin{array}{l}\text { Interest Coverage } \\
\text { Ratio }\end{array}$ & EBIT to interest expense & Percent & $\begin{array}{l}\text { Bursa Malaysia/Company's } \\
\text { Annual Accounts }\end{array}$ & - \\
\hline Size & Assets & $\begin{array}{l}\text { Millions of (Malaysian } \\
\text { ringgit in natural } \\
\text { logarithms) }\end{array}$ & $\begin{array}{l}\text { Bursa Malaysia/Company's } \\
\text { Annual Accounts }\end{array}$ & - \\
\hline Equity Volatility & $\begin{array}{l}\text { Standard deviation of day-to-day } \\
\text { logarithmic price changes. A } \\
\text { previous } 360 \text {-day price volatility } \\
\text { equals the annualized standard } \\
\text { deviation of the relative price } \\
\text { change of the } 360 \text { most recent } \\
\text { trading days' closing price. }\end{array}$ & percent & Data Stream & - \\
\hline Years to Maturity & Years to Maturity & $\begin{array}{l}\text { Years (in natural } \\
\text { logarithms) }\end{array}$ & Bloomberg & + \\
\hline Interaction & Time to maturity $*$ leverage & Author's Calculation & Author & - \\
\hline $\begin{array}{l}\text { Industrial } \\
\text { Production Index } \\
\text { (IPI) }\end{array}$ & $\begin{array}{l}\text { Quarterly growth rate in } \\
\text { Industrial Production }\end{array}$ & $\begin{array}{l}\text { Percent (in natural } \\
\text { logarithms) }\end{array}$ & Data Stream & - \\
\hline $\begin{array}{l}\text { Consumer Price } \\
\text { Index/Inflation }\end{array}$ & $\begin{array}{l}\text { Annual percentage change in the } \\
\text { Consumer Price Index }\end{array}$ & $\begin{array}{l}\text { Percent (in natural } \\
\text { logarithms) }\end{array}$ & Data Stream & + \\
\hline GDP Growth & Annual real GDP growth & Percent & Data Stream & - \\
\hline Slope & $\begin{array}{l}\text { Difference between 10- and 2- } \\
\text { year Malaysian Treasury Rate }\end{array}$ & Percent & Data Stream & - \\
\hline
\end{tabular}

Table 3: Description of Variables and Expected Signs 


\begin{tabular}{|c|c|c|c|c|c|c|c|c|c|c|c|}
\hline & ROA & CAPT & Leverage & $\begin{array}{c}\text { Interest } \\
\text { Coverage }\end{array}$ & Volatility & Ln (Size) & $\begin{array}{c}\text { Ln } \\
\text { (YrtoMat) }\end{array}$ & $\begin{array}{c}\text { Ln } \\
(\triangle \text { IPI })\end{array}$ & $\begin{array}{c}\mathbf{L n} \\
(\triangle \mathrm{CPI})\end{array}$ & $\begin{array}{c}\text { GDP } \\
\text { Growth }\end{array}$ & Slope \\
\hline ROA & 1 & & & & & & & & & & \\
\hline CAPT & $0.0575^{*}$ & 1 & & & & & & & & & \\
\hline Leverage & $0.152^{*}$ & $-0.482^{*}$ & 1 & & & & & & & & \\
\hline $\begin{array}{l}\text { Interest } \\
\text { Coverage }\end{array}$ & $0.458^{*}$ & $0.214^{*}$ & $-0.164^{*}$ & 1 & & & & & & & \\
\hline Volatility & $-0.138^{*}$ & $0.161^{*}$ & -0.00443 & $-0.106^{*}$ & 1 & & & & & & \\
\hline $\operatorname{Ln}($ Size $)$ & $-0.217^{*}$ & $-0.539^{*}$ & $-0.189^{*}$ & $-0.0912^{*}$ & $-0.378^{*}$ & 1 & & & & & \\
\hline LnYrtoMat & -0.0392 & $-0.139^{*}$ & $-0.0682^{*}$ & -0.0192 & $-0.153^{*}$ & $0.172^{*}$ & 1 & & & & \\
\hline $\operatorname{Ln}(\triangle \mathrm{IPI})$ & -0.00282 & 0.0002 & -0.0181 & -0.00904 & $0.129^{*}$ & 0.0153 & 0.0114 & 1 & & & \\
\hline $\operatorname{Ln}(\triangle \mathrm{CPI})$ & -0.0306 & 0.0369 & 0.0193 & $-0.0683^{*}$ & $0.191^{*}$ & $-0.119^{*}$ & -0.00774 & $0.0679^{*}$ & 1 & & \\
\hline GDP Growth & 0.0337 & -0.0116 & -0.0023 & 0.0256 & $-0.0916^{*}$ & 0.02 & -0.0148 & $0.102^{*}$ & $0.0964^{*}$ & 1 & \\
\hline Slope & -0.00331 & 0.0284 & 0.0403 & $0.0822^{*}$ & -0.0392 & $-0.0473^{*}$ & 0.00132 & $-0.0748^{*}$ & 0.027 & $0.0700^{*}$ & 1 \\
\hline
\end{tabular}

Notes: Table 4 reports pairwise correlation coefficients for the firm-specific, bond-specific, and macroeconomic variables included in our estimations. No multicollinearity problems are evidenced. **, *significance at $5 \% ; 1 \%$ respectively. Table reports significance levels for the hypothesis test $\mathrm{H} 0:$ rho $=0$ against the two-sided alternative. Here CAPT: Capitalization ratio (Equity/Capital), Int Covg.: Interest Coverage (EBIT/Interest Expense), Ln YrtoMat: Years to Maturity in natural logarithm, Ln ( $\triangle \mathrm{IPI})$ : Change in Industrial Production Index in natural logarithm, Ln $(\triangle \mathrm{CPI})$ : Change in Consumer Price Index in natural logarithm.

Table 4: Correlation Matrix (Conventional Bonds) 


\begin{tabular}{|c|c|c|c|c|c|c|c|c|c|c|c|}
\hline & $\overline{\mathrm{ROA}}$ & $\overline{\text { CAPT }}$ & Leverage & Int Covg. & Ln size & " Volatility & LnYrtoMat & In IPI & In CPI & Slope & $\begin{array}{c}\text { GDP } \\
\text { Growth }\end{array}$ \\
\hline ROA & 1 & & & & & & & & & & \\
\hline CAPT & $0.2242^{*}$ & 1 & & & & & & & & & \\
\hline Leverage & -0.0108 & $-0.4982 *$ & 1 & & & & & & & & \\
\hline Interest & & & & & & & & & & & \\
\hline Coverage & $0.5038^{*}$ & $0.3124^{*}$ & $-0.1861 *$ & 1 & & & & & & & \\
\hline Volatility & $-0.0879 *$ & $-0.3178 *$ & $-0.2623^{*}$ & -0.0257 & 1 & & & & & & \\
\hline $\operatorname{Ln}($ Size $)$ & $-0.2638 *$ & $-0.0937^{*}$ & $0.1526^{*}$ & $-0.1742^{*}$ & $-0.3611 *$ & 1 & & & & & \\
\hline LnYrtoMat & $0.1205^{*}$ & 0.0055 & $-0.1688 *$ & $0.11 *$ & $0.2616^{*}$ & $-0.1442^{*}$ & 1 & & & & \\
\hline $\operatorname{Ln}(\triangle \mathrm{IPI})$ & 0.0507 & $-0.1090 *$ & -0.0274 & -0.0105 & $0.3186^{*}$ & $-0.1711^{*}$ & $0.2317^{*}$ & 1 & & & \\
\hline $\operatorname{Ln}(\triangle \mathrm{CPI})$ & 0.0111 & $-0.1519 *$ & -0.0212 & -0.027 & $0.4^{*}$ & -0.0481 & $0.3095^{*}$ & $0.7230^{*}$ & 1 & & \\
\hline GDP Growth & $0.0680^{*}$ & 0.0123 & -0.0009 & 0.026 & 0.0084 & -0.1252 & 0.0232 & $0.1683^{*}$ & -0.0201 & 1 & \\
\hline Slope & -0.0195 & $0.0961 *$ & -0.0491 & 0.1473 & -0.0503 & -0.0043 & -0.0099 & $-0.4912 *$ & $-0.1678^{*}$ & $0.079 *$ & 1 \\
\hline
\end{tabular}

Notes: Table 5 reports the pairwise correlation coefficients for the firm-specific, bond-specific, and macroeconomic variables included in our estimations. No multicollinearity problems were evidenced. ** and * represent significance at the $5 \%$ and $1 \%$ levels, respectively. The table reports significance levels for the hypothesis test H0: rho $=0$ against the two-sided alternative. Here, CAPT: Capitalization ratio (Equity/Capital); .: Interest Coverage (EBIT/Interest Expense), LnYrtoMat: Years to Maturity in natural logarithm, Ln $(\triangle \mathrm{IPI})$ : Change in Industrial Production Index in natural logarithm, Ln $(\triangle \mathrm{CPI})$ : Change in Consumer Price Index in natural logarithm.

\section{Table 5: Correlation Matrix (Sukuk)}




\begin{tabular}{|c|c|c|c|c|c|c|c|c|c|c|c|c|c|c|c|c|}
\hline \multicolumn{9}{|c|}{ Conventional Bonds } & \multicolumn{8}{|c|}{ Sukuk } \\
\hline & 3-year & & 5-year & & 7-year & & 10-year & & 3-year & & 5-year & & 7-year & & 10-year & \\
\hline Year & Mean & St. Dev. & Mean & St. Dev. & Mean & St. Dev. & Mean & St. Dev. & Mean & St. Dev. & Mean & St. Dev. & Mean & St. Dev. & Mean & St. Dev. \\
\hline 2002 & & -- & -0.019 & .0 & -- & -- & -- & -- & 0.025 & 0.006 & 0.035 & 0.001 & -- & -- & -- & -- \\
\hline 2003 & 0.021 & 0.020 & 0.002 & 0.020 & -- & -- & -- & -- & 0.013 & 0.006 & 0.033 & 0.006 & -- & -- & -- & -- \\
\hline 2004 & 0.018 & 0.015 & 0.008 & 0.014 & -- & -- & -- & -- & 0.008 & 0.006 & 0.018 & 0.014 & 0.013 & 0.000 & -- & -- \\
\hline 2005 & 0.017 & 0.02 & 0.016 & 0.019 & 0.031 & 0.016 & -- & -- & 0.011 & 0.008 & 0.020 & 0.017 & 0.018 & 0.006 & 0.036 & 0.015 \\
\hline 2006 & 0.026 & 0.03 & 0.020 & 0.023 & 0.024 & 0.015 & -- & -- & 0.020 & 0.020 & 0.024 & 0.021 & 0.032 & 0.023 & 0.025 & 0.019 \\
\hline 2007 & 0.016 & 0.012 & 0.025 & 0.034 & 0.022 & 0.016 & -- & -- & 0.015 & 0.014 & 0.027 & 0.036 & 0.040 & 0.040 & 0.028 & 0.021 \\
\hline 2008 & 0.017 & 0.011 & 0.026 & 0.034 & 0.019 & 0.015 & -- & -- & 0.022 & 0.032 & 0.018 & 0.008 & 0.054 & 0.064 & 0.025 & 0.020 \\
\hline 2009 & 0.019 & 0.028 & 0.026 & 0.038 & 0.021 & 0.016 & -- & -- & 0.018 & 0.010 & 0.019 & 0.010 & 0.047 & 0.061 & 0.046 & 0.050 \\
\hline 2010 & 0.010 & 0.001 & 0.024 & 0.042 & 0.020 & 0.016 & -- & -- & 0.011 & 0.008 & 0.016 & 0.010 & 0.034 & 0.044 & 0.062 & 0.058 \\
\hline 2011 & 0.008 & 0.006 & 0.015 & 0.023 & 0.019 & 0.015 & 0.012 & 0.0025 & 0.008 & 0.006 & 0.016 & 0.021 & 0.028 & 0.048 & 0.045 & 0.051 \\
\hline 2012 & 0.006 & 0.003 & 0.010 & 0.020 & 0.021 & 0.025 & 0.009 & 0.0018 & 0.005 & 0.004 & 0.013 & 0.027 & 0.016 & 0.006 & 0.032 & 0.041 \\
\hline 2013 & 0.005 & 0.003 & 0.006 & 0.009 & 0.015 & 0.016 & 0.006 & 0.002 & 0.005 & 0.005 & 0.005 & 0.004 & 0.011 & 0.003 & 0.026 & 0.036 \\
\hline Overall & 0.014 & 0.018 & 0.020 & 0.031 & 0.020 & 0.018 & 0.0082 & 0.0029 & 0.014 & 0.013 & 0.018 & 0.020 & 0.035 & 0.044 & 0.036 & 0.041 \\
\hline
\end{tabular}




\begin{tabular}{|c|c|c|c|c|c|c|}
\hline \multirow[t]{2}{*}{ Variable } & \multicolumn{3}{|c|}{ Conventional Bonds } & \multicolumn{3}{|l|}{ Sukuk } \\
\hline & Mean & St. Dev. & Obs.: $\mathbf{n} \mathbf{T}$ & Mean & St. Dev. & Obs.: $n \times \mathbf{T}$ \\
\hline Bond/Sukuk-specific & & & & & & \\
\hline $\begin{array}{l}\text { Year To Maturity } \\
\text { Firm-specific }\end{array}$ & 3.225752 & 2.902176 & 2,238 & 2.84 & 2.22 & 979 \\
\hline ROA & .0182289 & .0268677 & 2,238 & .0145138 & .012496 & 979 \\
\hline Capitalization & .5482608 & .1732111 & 2,238 & .606712 & .1214616 & 979 \\
\hline Leverage & .2930784 & .1477036 & 2,238 & .2761216 & .1033539 & 979 \\
\hline Interest Coverage & 8.717283 & 15.6879 & 2,238 & 6.197747 & 10.27514 & 979 \\
\hline Volatility & .3190235 & .239902 & 2,238 & .3460204 & .2436026 & 979 \\
\hline $\begin{array}{l}\text { Size } \\
\text { Macro Factors }\end{array}$ & 35214.64 & 77540.38 & 2,238 & 20925.1 & 63632.07 & 979 \\
\hline $\operatorname{Ln}(\triangle \mathrm{IPI})$ & -4.1332 & 1.0616 & 2,238 & -4.166 & 6.597387 & 979 \\
\hline $\operatorname{Ln}(\triangle \mathrm{CPI})$ & -4.7217 & 1.3525 & 2,238 & -4.7729 & .0730073 & 979 \\
\hline GDP Growth & .0130902 & .0290443 & 2,238 & .013163 & .0289325 & 979 \\
\hline Slope & .0079436 & .0047963 & 2,238 & .0080153 & .0046743 & 979 \\
\hline
\end{tabular}

Notes: Here, ROA: return on Assets; Ln ( $\triangle \mathrm{IPI})$ : log of change in the Industrial Production Index; CPI: log of change in the Consumer Price Index in natural logarithms; and Size is total assets in millions of Malaysian ringgit.

Table 6b: Descriptive Statistics 


\begin{tabular}{|c|c|c|c|c|c|c|c|c|}
\hline & \multicolumn{4}{|c|}{ Conventional Bonds } & \multicolumn{4}{|c|}{ Sukuk } \\
\hline & [1] OLS & [2] RE & [3] FE & [4] FE-DR & [1] OLS & [2] RE & [3] FE & [4] FE-DR \\
\hline \multicolumn{9}{|l|}{ Firm-specific } \\
\hline ROA & $\begin{array}{c}-12.196^{* * * *} \\
(0.98)\end{array}$ & $\begin{array}{c}-0.396 \\
(2.30)\end{array}$ & $\begin{array}{l}0.333 \\
(1.93)\end{array}$ & $\begin{array}{l}0.333 \\
(1.92)\end{array}$ & $\begin{array}{c}-3.116 \\
(3.02)\end{array}$ & $\begin{array}{c}-1.707 \\
(4.10)\end{array}$ & $\begin{array}{c}-2.762 \\
(3.72)\end{array}$ & $\begin{array}{c}-2.762 \\
(3.73)\end{array}$ \\
\hline Capitalization & $\begin{array}{c}-2.127^{* * * *} \\
(0.23)\end{array}$ & $\begin{array}{c}-0.667 \\
(0.34)\end{array}$ & $\begin{array}{c}-0.279 \\
(0.32)\end{array}$ & $\begin{array}{c}-0.279 \\
(0.41)\end{array}$ & $\begin{array}{c}-1.075^{* * *} \\
(0.35)\end{array}$ & $\begin{array}{l}3.292^{*} \\
(1.54)\end{array}$ & $\begin{array}{l}1.326^{*} \\
(1.38)\end{array}$ & $\begin{array}{l}1.326^{*} \\
(1.64)\end{array}$ \\
\hline Leverage & $\begin{array}{c}-2.527^{* * * *} \\
(0.36)\end{array}$ & $\begin{array}{c}-2.402^{* * * *} \\
(0.44)\end{array}$ & $\begin{array}{c}-2.237^{* * * *} \\
(0.44)\end{array}$ & $\begin{array}{c}-2.237^{\text {*** }} \\
(0.47)\end{array}$ & $\begin{array}{c}-3.002^{* * * *} \\
(0.43)\end{array}$ & $\begin{array}{c}-0.305 \\
(1.74)\end{array}$ & $\begin{array}{c}-2.851^{*} \\
(1.32)\end{array}$ & $\begin{array}{c}-2.851^{*} \\
(1.58)\end{array}$ \\
\hline Interest Coverage & $\begin{array}{l}0.002 \\
(0.00)\end{array}$ & $\begin{array}{l}0.004 \\
(0.00)\end{array}$ & $\begin{array}{l}0.003 \\
(0.00)\end{array}$ & $\begin{array}{l}0.003 \\
(0.00)\end{array}$ & $\begin{array}{c}-0.010^{* * *} \\
(0.00)\end{array}$ & $\begin{array}{c}-0.002 \\
(0.00)\end{array}$ & $\begin{array}{c}-0.002 \\
(0.00)\end{array}$ & $\begin{array}{c}-0.002 \\
(0.00)\end{array}$ \\
\hline Ln (Size) & $\begin{array}{c}-0.328^{* * * *} \\
(0.02)\end{array}$ & $\begin{array}{c}-0.109^{*} \\
(0.05)\end{array}$ & $\begin{array}{c}-0.044 \\
(0.04)\end{array}$ & $\begin{array}{c}-0.044 \\
(0.05)\end{array}$ & $\begin{array}{c}-0.321^{* * * *} \\
(0.03)\end{array}$ & $\begin{array}{c}-0.008 \\
(0.11)\end{array}$ & $\begin{array}{c}-0.100 \\
(0.06)\end{array}$ & $\begin{array}{c}-0.100 * * \\
(0.06)\end{array}$ \\
\hline Volatility & $\begin{array}{c}0.596^{* * * *} \\
(0.16)\end{array}$ & $\begin{array}{l}0.304^{*} \\
(0.12)\end{array}$ & $\begin{array}{l}0.290^{*} \\
(0.11)\end{array}$ & $\begin{array}{l}0.290^{*} \\
(0.12)\end{array}$ & $\begin{array}{l}0.451^{*} \\
(0.17)\end{array}$ & $\begin{array}{l}0.297 \\
(0.17)\end{array}$ & $\begin{array}{l}0.277 \\
(0.14)\end{array}$ & $\begin{array}{l}0.277 \\
(0.15)\end{array}$ \\
\hline Bond-/Sukuk-specific & & & & & & & & \\
\hline Ln (Year to Maturity) & $\begin{array}{c}-0.060 \\
(0.03)\end{array}$ & $\begin{array}{c}-0.141^{* * *} \\
(0.03)\end{array}$ & $\begin{array}{c}-0.157^{* * * *} \\
(0.04)\end{array}$ & $\begin{array}{c}-0.157^{\text {*** }} \\
(0.04)\end{array}$ & $\begin{array}{c}-0.184^{* * * *} \\
(0.05)\end{array}$ & $\begin{array}{c}-0.175^{* * *} \\
(0.05)\end{array}$ & $\begin{array}{c}-0.220^{* * * *} \\
(0.05)\end{array}$ & $\begin{array}{c}-0.220^{* * * *} \\
(0.05)\end{array}$ \\
\hline Yr to Maturity* Debt/assets & $\begin{array}{l}0.077^{*} \\
(0.04)\end{array}$ & $\begin{array}{c}0.308^{* * * *} \\
(0.03)\end{array}$ & $\begin{array}{c}0.390^{* * * *} \\
(0.05)\end{array}$ & $\begin{array}{c}0.390^{* * * *} \\
(0.07)\end{array}$ & $\begin{array}{c}0.443^{* * * *} \\
(0.08)\end{array}$ & $\begin{array}{c}0.508^{* * * *} \\
(0.10)\end{array}$ & $\begin{array}{c}0.728^{* * * *} \\
(0.10)\end{array}$ & $\begin{array}{c}0.728^{* * * *} \\
(0.10)\end{array}$ \\
\hline Macro Factors & & & & & & & & \\
\hline $\operatorname{Ln}(\triangle \mathrm{IPI})$ & $\begin{array}{l}0.017 \\
(0.03)\end{array}$ & $\begin{array}{l}0.024 \\
(0.02)\end{array}$ & $\begin{array}{l}0.025 \\
(0.02)\end{array}$ & $\begin{array}{l}0.025 \\
(0.03)\end{array}$ & $\begin{array}{l}0.033 \\
(0.03)\end{array}$ & $\begin{array}{l}0.035 \\
(0.03)\end{array}$ & $\begin{array}{l}0.040 \\
(0.02)\end{array}$ & $\begin{array}{l}0.040 \\
(0.02)\end{array}$ \\
\hline $\operatorname{Ln}(\triangle \mathrm{CPI})$ & $\begin{array}{l}0.008 \\
(0.02)\end{array}$ & $\begin{array}{l}0.001 \\
(0.01)\end{array}$ & $\begin{array}{c}-0.002 \\
(0.01)\end{array}$ & $\begin{array}{c}-0.002 \\
(0.02)\end{array}$ & $\begin{array}{l}0.037^{*} \\
(0.02)\end{array}$ & $\begin{array}{l}0.018 \\
(0.01)\end{array}$ & $\begin{array}{l}0.011 \\
(0.01)\end{array}$ & $\begin{array}{l}0.011 \\
(0.01)\end{array}$ \\
\hline GDP Growth & $\begin{array}{c}-1.435 \\
(1.17)\end{array}$ & $\begin{array}{c}-1.767 \\
(0.92)\end{array}$ & $\begin{array}{c}-1.743^{*} \\
(0.84)\end{array}$ & $\begin{array}{c}-1.743^{*} \\
(0.83)\end{array}$ & $\begin{array}{c}-0.122 \\
(0.96)\end{array}$ & $\begin{array}{c}-0.303 \\
(0.81)\end{array}$ & $\begin{array}{c}-0.193 \\
(0.72)\end{array}$ & $\begin{array}{c}-0.193 \\
(0.74)\end{array}$ \\
\hline Slope (10yr- 2yr) & $\begin{array}{c}-3.672 \\
(5.73)\end{array}$ & $\begin{array}{c}-1.740 \\
(3.79)\end{array}$ & $\begin{array}{c}-2.547 \\
(3.71)\end{array}$ & $\begin{array}{c}-2.547 \\
(3.45)\end{array}$ & $\begin{array}{c}34.936^{* * * *} \\
(7.09)\end{array}$ & $\begin{array}{c}29.760^{* * * *} \\
(6.21)\end{array}$ & $\begin{array}{c}26.628^{* * * *} \\
(5.27)\end{array}$ & $\begin{array}{c}26.628^{* * * *} \\
(5.80)\end{array}$ \\
\hline _cons & $\begin{array}{l}0.436 \\
(0.35) \\
\end{array}$ & $\begin{array}{c}-3.832^{* * * *} \\
(0.67) \\
\end{array}$ & $\begin{array}{c}-3.439^{* * *} \\
(0.59) \\
\end{array}$ & $\begin{array}{c}-3.439^{* * * *} \\
(0.71)\end{array}$ & $\begin{array}{c}-0.446 \\
(0.64) \\
\end{array}$ & $\begin{array}{c}-8.143^{* * * *} \\
(2.32) \\
\end{array}$ & $\begin{array}{c}-3.933^{* *} \\
(1.40) \\
\end{array}$ & $\begin{array}{c}-3.933^{* *} \\
(1.44) \\
\end{array}$ \\
\hline $\begin{array}{l}N \\
\text { Adj. } \mathrm{R}^{2}\end{array}$ & $\begin{array}{l}2238 \\
.345\end{array}$ & 2238 & $\begin{array}{l}2238 \\
.090\end{array}$ & 2238 & $\begin{array}{l}979 \\
.278\end{array}$ & 979 & $\begin{array}{l}979 \\
.093\end{array}$ & 979 \\
\hline Firm Fixed Effects & No & Yes & Yes & Yes & No & Yes & Yes & Yes \\
\hline Sector Fixed Effects & No & Yes & Yes & Yes & No & Yes & Yes & Yes \\
\hline Cluster (Time) & Yes & Yes & Yes & No & Yes & Yes & Yes & No \\
\hline
\end{tabular}




\begin{tabular}{|c|c|c|c|c|c|c|c|c|}
\hline & \multicolumn{4}{|c|}{ Conventional Bonds } & \multicolumn{4}{|c|}{ 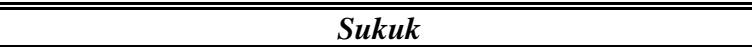 } \\
\hline & [1] OLS & [2] RE & [3] FE & [4] FE-DR & [1] OLS & [2] RE & [3] FE & [4] FE-DR \\
\hline \multicolumn{9}{|l|}{ Firm-specific } \\
\hline ROA & $\begin{array}{c}-10.480^{* *} \\
(3.12)\end{array}$ & $\begin{array}{c}-0.853 \\
(3.59)\end{array}$ & $\begin{array}{l}0.287 \\
(2.59)\end{array}$ & $\begin{array}{l}0.287 \\
(2.05)\end{array}$ & $\begin{array}{c}-2.954 \\
(9.46)\end{array}$ & $\begin{array}{c}-11.204 \\
(11.31)\end{array}$ & $\begin{array}{c}-12.616 \\
(11.59)\end{array}$ & $\begin{array}{c}-12.616 \\
(9.93)\end{array}$ \\
\hline Capitalization & $\begin{array}{c}-2.357^{* * * *} \\
(0.51)\end{array}$ & $\begin{array}{c}-1.821^{* * *} \\
(0.70)\end{array}$ & $\begin{array}{c}-1.691^{*} \\
(0.69)\end{array}$ & $\begin{array}{c}-1.691^{*} \\
(0.62)\end{array}$ & $\begin{array}{c}-2.399^{\text {**** }} \\
(0.58)\end{array}$ & $\begin{array}{l}1.006 \\
(3.81)\end{array}$ & $\begin{array}{c}-0.492 \\
(4.27)\end{array}$ & $\begin{array}{c}-0.492 \\
(4.24)\end{array}$ \\
\hline Leverage & $\begin{array}{c}-3.162^{* * * *} \\
(0.55)\end{array}$ & $\begin{array}{c}-4.369^{* *} \\
(1.40)\end{array}$ & $\begin{array}{c}-3.874^{*} \\
(1.46)\end{array}$ & $\begin{array}{c}-3.874^{* * *} \\
(1.29)\end{array}$ & $\begin{array}{c}-5.482^{* * * * *} \\
(1.18)\end{array}$ & $\begin{array}{c}-8.275^{*} \\
(3.58)\end{array}$ & $\begin{array}{c}-9.751^{*} \\
(4.21)\end{array}$ & $\begin{array}{c}-9.751^{*} \\
(3.90)\end{array}$ \\
\hline Interest Coverage & $\begin{array}{l}0.000 \\
(0.00)\end{array}$ & $\begin{array}{c}-0.001 \\
(0.00)\end{array}$ & $\begin{array}{l}0.001 \\
(0.00)\end{array}$ & $\begin{array}{l}0.001 \\
(0.00)\end{array}$ & $\begin{array}{c}-0.012^{* * * *} \\
(0.00)\end{array}$ & $\begin{array}{c}-0.003 \\
(0.00)\end{array}$ & $\begin{array}{c}-0.002 \\
(0.00)\end{array}$ & $\begin{array}{c}-0.002 \\
(0.00)\end{array}$ \\
\hline Ln (Size) & $\begin{array}{c}-0.348^{* * *} \\
(0.04)\end{array}$ & $\begin{array}{c}-0.282^{*} \\
(0.11)\end{array}$ & $\begin{array}{c}-0.255^{*} \\
(0.11)\end{array}$ & $\begin{array}{c}-0.255^{*} \\
(0.11)\end{array}$ & $\begin{array}{c}-0.422^{* * * *} \\
(0.05)\end{array}$ & $\begin{array}{l}0.622 \\
(1.20)\end{array}$ & $\begin{array}{c}0.458^{* *} \\
(1.20)\end{array}$ & $\begin{array}{c}0.458^{* *} \\
(1.33)\end{array}$ \\
\hline Volatility & $\begin{array}{l}0.358 \\
(0.22)\end{array}$ & $\begin{array}{l}0.178 \\
(0.15)\end{array}$ & $\begin{array}{l}0.139 \\
(0.13)\end{array}$ & $\begin{array}{l}0.139 \\
(0.14)\end{array}$ & $\begin{array}{l}0.199 \\
(0.30)\end{array}$ & $\begin{array}{l}0.064 \\
(0.33)\end{array}$ & $\begin{array}{l}0.064 \\
(0.32)\end{array}$ & $\begin{array}{l}0.064 \\
(0.30)\end{array}$ \\
\hline Bond-/Sukuk-specific & & & & & & & & \\
\hline Ln (Year to Maturity) & $\begin{array}{c}-0.210^{* *} \\
(0.07)\end{array}$ & $\begin{array}{c}-0.208^{* * *} \\
(0.06)\end{array}$ & $\begin{array}{c}-0.212^{* * * *} \\
(0.06)\end{array}$ & $\begin{array}{c}-0.212^{* * *} \\
(0.05)\end{array}$ & $\begin{array}{c}-0.625^{* * * *} \\
(0.16)\end{array}$ & $\begin{array}{c}-0.583^{* * *} \\
(0.14)\end{array}$ & $\begin{array}{c}-0.592^{* * * *} \\
(0.13)\end{array}$ & $\begin{array}{c}-0.592^{* * *} \\
(0.11)\end{array}$ \\
\hline Yr to Maturity* Debt/assets & $\begin{array}{c}0.979^{* * * *} \\
(0.18)\end{array}$ & $\begin{array}{c}1.114^{* * * *} \\
(0.12)\end{array}$ & $\begin{array}{c}1.082^{* * * *} \\
(0.13)\end{array}$ & $\begin{array}{c}1.082^{* * * *} \\
(0.10)\end{array}$ & $\begin{array}{c}1.881^{* * *} \\
(0.41)\end{array}$ & $\begin{array}{c}2.064^{* * * *} \\
(0.37)\end{array}$ & $\begin{array}{c}2.053^{* * * *} \\
(0.38)\end{array}$ & $\begin{array}{c}2.053^{* * * *} \\
(0.32)\end{array}$ \\
\hline Macro Factors & & & & & & & & \\
\hline $\operatorname{Ln}(\triangle \mathrm{IPI})$ & $\begin{array}{l}0.101^{*} \\
(0.04)\end{array}$ & $\begin{array}{c}0.116^{* * *} \\
(0.03)\end{array}$ & $\begin{array}{c}0.111^{* * * *} \\
(0.03)\end{array}$ & $\begin{array}{c}0.111^{* * * *} \\
(0.03)\end{array}$ & $\begin{array}{l}0.155^{*} \\
(0.07)\end{array}$ & $\begin{array}{l}0.139^{*} \\
(0.06)\end{array}$ & $\begin{array}{l}0.140^{*} \\
(0.06)\end{array}$ & $\begin{array}{l}0.140^{*} \\
(0.06)\end{array}$ \\
\hline $\operatorname{Ln}(\triangle \mathrm{CPI})$ & $\begin{array}{l}0.012 \\
(0.03)\end{array}$ & $\begin{array}{c}-0.006 \\
(0.03)\end{array}$ & $\begin{array}{c}-0.015 \\
(0.03)\end{array}$ & $\begin{array}{c}-0.015 \\
(0.02)\end{array}$ & $\begin{array}{l}0.071 \\
(0.04)\end{array}$ & $\begin{array}{l}0.065 \\
(0.05)\end{array}$ & $\begin{array}{l}0.073 \\
(0.05)\end{array}$ & $\begin{array}{l}0.073 \\
(0.05)\end{array}$ \\
\hline GDP Growth & $\begin{array}{l}-2.357 \\
(1.31)\end{array}$ & $\begin{array}{c}-1.738 \\
(1.01)\end{array}$ & $\begin{array}{l}-1.795 \\
(1.02)\end{array}$ & $\begin{array}{c}-1.795 \\
(1.18)\end{array}$ & $\begin{array}{l}0.262 \\
(1.74)\end{array}$ & $\begin{array}{l}1.053 \\
(1.68)\end{array}$ & $\begin{array}{l}0.945 \\
(1.58)\end{array}$ & $\begin{array}{l}0.945 \\
(1.89)\end{array}$ \\
\hline Slope (10- and 2-year) & $\begin{array}{c}22.590^{* * *} \\
(7.49)\end{array}$ & $\begin{array}{l}11.320 \\
(9.09)\end{array}$ & $\begin{array}{c}18.230^{*} \\
(8.64)\end{array}$ & $\begin{array}{l}18.230 \\
(10.12)\end{array}$ & $\begin{array}{c}62.851^{* * * *} \\
(12.92)\end{array}$ & $\begin{array}{l}34.685^{*} \\
(13.52)\end{array}$ & $\begin{array}{c}37.494^{* *} \\
(13.74)\end{array}$ & $\begin{array}{l}37.494^{*} \\
(14.02)\end{array}$ \\
\hline _cons & $\begin{array}{r}0.509 \\
(0.79) \\
\end{array}$ & $\begin{array}{l}0.367 \\
(1.96) \\
\end{array}$ & $\begin{array}{c}-0.582 \\
(1.75) \\
\end{array}$ & $\begin{array}{c}-0.582 \\
(1.63) \\
\end{array}$ & $\begin{array}{r}1.588 \\
(1.12) \\
\end{array}$ & $\begin{array}{c}-10.709 \\
(14.28) \\
\end{array}$ & $\begin{array}{r}-4.896 \\
(11.80) \\
\end{array}$ & $\begin{array}{l}-4.896 \\
(12.84) \\
\end{array}$ \\
\hline $\begin{array}{l}N \\
\text { Adj. } \mathrm{R}^{2}\end{array}$ & $\begin{array}{l}377 \\
.4487\end{array}$ & 377 & $\begin{array}{c}377 \\
.2853\end{array}$ & 377 & $\begin{array}{l}228 \\
.469\end{array}$ & 228 & $\begin{array}{l}228 \\
.291\end{array}$ & 228 \\
\hline Firm Fixed Effects & No & Yes & Yes & Yes & No & Yes & Yes & Yes \\
\hline Sector Fixed Effects & No & Yes & Yes & Yes & No & Yes & Yes & Yes \\
\hline Cluster (Time) & Yes & Yes & Yes & No & Yes & Yes & Yes & No \\
\hline
\end{tabular}

Notes: The dependent variable is the corporate bond/sukuk spread. Standard errors are in parentheses. * $\mathrm{p}<0.05$, ** $\mathrm{p}<0.01$, and $* * * \mathrm{p}<0.001$. The dependent variable is $\ln$ (CB spread) and ln (sukuk spread) for conventional bonds and sukuk, respectively. (OLS)[1] Ordinary least squares, (REM) [2] random effects model,

(FEM) [3] fixed effects model, (FE-DR), and [4] fixed effects with Driscoll and Kraay's (1998) standard errors.

Table 8: Determinants of Corporate Bonds/Sukuk-3-year Maturity 


\begin{tabular}{|c|c|c|c|c|c|c|c|c|}
\hline & \multicolumn{4}{|c|}{ "Conventional Bonds } & \multicolumn{4}{|c|}{ Sukuk } \\
\hline & [1] OLS & [2] RE & [3] FE & [4] FE-DR & [1] OLS & [2] RE & [3] FE & [4] FE-DR \\
\hline \multicolumn{9}{|l|}{ Firm-specific } \\
\hline \multirow[t]{2}{*}{ ROA } & $-12.993^{* * *}$ & -2.763 & -2.009 & -2.009 & -0.029 & 0.872 & 0.761 & 0.761 \\
\hline & $(0.88)$ & $(1.85)$ & $(1.43)$ & $(1.77)$ & $(3.46)$ & $(5.60)$ & $(5.50)$ & $(5.85)$ \\
\hline \multirow[t]{2}{*}{ Capitalization } & $-1.724^{* * * *}$ & -0.484 & -0.220 & -0.220 & 0.778 & 0.836 & 1.079 & 1.079 \\
\hline & $(0.25)$ & $(0.45)$ & $(0.43)$ & $(0.54)$ & $(0.51)$ & $(2.40)$ & $(2.35)$ & $(2.13)$ \\
\hline \multirow[t]{2}{*}{ Leverage } & $-1.876^{* * * *}$ & $-2.139^{* * *}$ & $-2.073^{* * * *}$ & $-2.073^{* *}$ & -0.593 & -3.025 & -2.721 & -2.721 \\
\hline & $(0.32)$ & $(0.58)$ & $(0.58)$ & $(0.68)$ & $(0.83)$ & $(2.36)$ & $(2.26)$ & $(1.75)$ \\
\hline \multirow[t]{2}{*}{ Interest Coverage } & 0.0004 & 0.0004 & 0.0001 & 0.00001 & $-0.022^{* * *}$ & $-0.008^{* *}$ & $-0.008^{* *}$ & $-0.008^{* *}$ \\
\hline & $(0.00)$ & $(0.00)$ & $(0.00)$ & $(0.00)$ & $(0.00)$ & $(0.00)$ & $(0.00)$ & $(0.00)$ \\
\hline \multirow[t]{2}{*}{ Ln (Size) } & $-0.337^{* * *}$ & $-0.171^{*}$ & -0.122 & -0.122 & $-0.190^{* * *}$ & $-0.261^{* *}$ & $-0.184 * *$ & $-0.184 * *$ \\
\hline & $(0.02)$ & $(0.08)$ & $(0.06)$ & $(0.06)$ & $(0.05)$ & $(0.09)$ & $(0.11)$ & $(0.13)$ \\
\hline \multirow[t]{2}{*}{ Volatility } & $0.707^{* * *}$ & $0.279^{* * *}$ & $0.258^{*}$ & $0.258^{*}$ & 0.373 & $0.377^{*}$ & $0.376^{*}$ & 0.376 \\
\hline & $(0.18)$ & $(0.10)$ & $(0.10)$ & $(0.10)$ & $(0.20)$ & $(0.19)$ & $(0.19)$ & $(0.20)$ \\
\hline \multicolumn{9}{|l|}{ Bond-/Sukuk-specific } \\
\hline \multirow[t]{2}{*}{ Ln (Year to Maturity) } & $-0.151^{* *}$ & $-0.181^{* * *}$ & $-0.200^{* * *}$ & $-0.200^{* *}$ & $-0.172^{*}$ & -0.138 & -0.138 & -0.138 \\
\hline & $(0.05)$ & $(0.05)$ & $(0.05)$ & $(0.06)$ & $(0.08)$ & $(0.08)$ & $(0.08)$ & $(0.08)$ \\
\hline \multirow[t]{2}{*}{ Yr to Maturity* Debt/assets } & 0.070 & $0.311^{* * * *}$ & $0.403^{* * * *}$ & $0.403^{* * *}$ & $0.333^{*}$ & $0.630^{* * * *}$ & $0.648^{* * * *}$ & $0.648^{* * * *}$ \\
\hline & $(0.04)$ & $(0.05)$ & $(0.06)$ & $(0.08)$ & $(0.16)$ & $(0.16)$ & $(0.16)$ & $(0.15)$ \\
\hline \multicolumn{9}{|l|}{ Macro Factors } \\
\hline \multirow[t]{2}{*}{$\operatorname{Ln}(\triangle \mathrm{IPI})$} & -0.011 & 0.002 & 0.004 & 0.004 & -0.021 & -0.000 & 0.001 & 0.001 \\
\hline & $(0.03)$ & $(0.03)$ & $(0.02)$ & $(0.03)$ & $(0.04)$ & $(0.03)$ & $(0.03)$ & $(0.03)$ \\
\hline \multirow[t]{2}{*}{$\operatorname{Ln}(\triangle \mathrm{CPI})$} & 0.022 & 0.012 & 0.010 & 0.010 & 0.026 & -0.003 & -0.004 & -0.004 \\
\hline & $(0.02)$ & $(0.01)$ & $(0.01)$ & $(0.01)$ & $(0.04)$ & $(0.02)$ & $(0.02)$ & $(0.02)$ \\
\hline \multirow[t]{2}{*}{ GDP Growth } & -1.474 & -1.823 & -1.836 & -1.836 & 0.247 & 0.251 & 0.239 & 0.239 \\
\hline & $(1.48)$ & $(1.07)$ & $(0.99)$ & $(0.94)$ & $(2.11)$ & $(1.54)$ & $(1.51)$ & $(1.83)$ \\
\hline \multirow[t]{2}{*}{ Slope (10- and 2-year) } & -6.433 & -3.800 & -5.402 & -5.402 & $45.249^{* * *}$ & $29.229^{* * * *}$ & $29.288^{* * * *}$ & $29.288^{*}$ \\
\hline & $(5.41)$ & $(4.03)$ & $(4.07)$ & $(2.91)$ & $(12.75)$ & $(7.93)$ & $(8.13)$ & $(10.90)$ \\
\hline \multirow[t]{2}{*}{ _cons } & 0.117 & $-3.238^{* * *}$ & $-2.771^{* *}$ & $-2.771^{* *}$ & $-3.574^{* *}$ & -3.349 & -3.521 & -3.521 \\
\hline & $(0.34)$ & $(0.88)$ & $(0.80)$ & $(0.86)$ & $(1.05)$ & $(2.31)$ & $(2.17)$ & $(2.14)$ \\
\hline$N$ & 1455 & 1455 & 1455 & 1455 & 516 & 516 & 516 & 516 \\
\hline Adj. $\mathrm{R}^{2}$ & .390 & & .094 & & .224 & & .065 & \\
\hline Firm Fixed Effects & No & Yes & Yes & Yes & No & Yes & Yes & Yes \\
\hline Sector Fixed Effects & No & Yes & Yes & Yes & No & Yes & Yes & Yes \\
\hline Cluster (Time) & Yes & Yes & Yes & No & Yes & Yes & Yes & No \\
\hline
\end{tabular}




\begin{tabular}{|c|c|c|c|c|c|c|c|c|}
\hline & \multicolumn{4}{|c|}{ Conventional Bonds } & \multicolumn{4}{|c|}{ Sukuk } \\
\hline & [1] OLS & [2] RE & [3] FE & [4] FE-DR & [1] OLS & [2] RE & [3] FE & [4] FE-DR \\
\hline \multicolumn{9}{|l|}{ Firm-specific } \\
\hline ROA & $\begin{array}{c}-0.659 \\
(4.21)\end{array}$ & $\begin{array}{l}0.588 \\
(3.68)\end{array}$ & $\begin{array}{l}0.442 \\
(3.63)\end{array}$ & $\begin{array}{l}0.442 \\
(2.88)\end{array}$ & $\begin{array}{c}-23.412^{*} \\
(9.97)\end{array}$ & $\begin{array}{c}-4.938 \\
(5.02)\end{array}$ & $\begin{array}{c}-4.938 \\
(4.90)\end{array}$ & $\begin{array}{c}-4.938 \\
(5.65)\end{array}$ \\
\hline Capitalization & $\begin{array}{c}-2.461^{\text {**** }} \\
(0.67)\end{array}$ & $\begin{array}{l}0.376 \\
(0.57)\end{array}$ & $\begin{array}{l}0.207 \\
(0.53)\end{array}$ & $\begin{array}{l}0.207 \\
(0.52)\end{array}$ & $\begin{array}{l}2.889 \\
(2.14)\end{array}$ & $\begin{array}{c}-5.234^{*} \\
(2.32)\end{array}$ & $\begin{array}{c}-5.234^{*} \\
(2.26)\end{array}$ & $\begin{array}{c}-5.234 * \\
(2.94)\end{array}$ \\
\hline Leverage & $\begin{array}{c}-3.378^{* * *} \\
(0.75)\end{array}$ & $\begin{array}{c}-0.917 \\
(0.85)\end{array}$ & $\begin{array}{c}-0.955 \\
(0.87)\end{array}$ & $\begin{array}{c}-0.955 \\
(0.85)\end{array}$ & $\begin{array}{l}4.587 \\
(2.73)\end{array}$ & $\begin{array}{c}-8.577^{* *} \\
(3.27)\end{array}$ & $\begin{array}{c}-8.577^{*} \\
(3.19)\end{array}$ & $\begin{array}{c}-8.577 \\
(3.79)\end{array}$ \\
\hline Interest Coverage & $\begin{array}{l}0.003 \\
(0.01)\end{array}$ & $\begin{array}{c}0.026^{* *} \\
(0.01)\end{array}$ & $\begin{array}{c}0.026^{* * *} \\
(0.01)\end{array}$ & $\begin{array}{c}0.026^{* * *} \\
(0.01)\end{array}$ & $\begin{array}{c}0.042^{\text {**** }} \\
(0.01)\end{array}$ & $\begin{array}{l}0.017^{*} \\
(0.01)\end{array}$ & $\begin{array}{l}0.017^{*} \\
(0.01)\end{array}$ & $\begin{array}{l}0.017 \\
(0.01)\end{array}$ \\
\hline Ln (Size) & $\begin{array}{c}-0.347^{\text {*** }} \\
(0.06)\end{array}$ & $\begin{array}{l}0.036 \\
(0.08)\end{array}$ & $\begin{array}{l}0.018 \\
(0.07)\end{array}$ & $\begin{array}{l}0.018 \\
(0.08)\end{array}$ & $\begin{array}{c}-0.196 \\
(0.17)\end{array}$ & $\begin{array}{c}-0.438 \\
(0.26)\end{array}$ & $\begin{array}{c}-0.438 \\
(0.26)\end{array}$ & $\begin{array}{c}-0.438 * * \\
(0.30)\end{array}$ \\
\hline Volatility & $\begin{array}{c}0.773^{* * *} \\
(0.20)\end{array}$ & $\begin{array}{l}0.479^{*} \\
(0.24)\end{array}$ & $\begin{array}{l}0.460 \\
(0.23)\end{array}$ & $\begin{array}{l}0.460 \\
(0.23)\end{array}$ & $\begin{array}{c}-0.142 \\
(0.38)\end{array}$ & $\begin{array}{l}0.302 \\
(0.20)\end{array}$ & $\begin{array}{l}0.302 \\
(0.20)\end{array}$ & $\begin{array}{l}0.302 \\
(0.20)\end{array}$ \\
\hline Bond-/Sukuk-specific & & & & & & & & \\
\hline Ln (Year to Maturity) & $\begin{array}{c}-0.003 \\
(0.10)\end{array}$ & $\begin{array}{l}0.100 \\
(0.09)\end{array}$ & $\begin{array}{l}0.085 \\
(0.09)\end{array}$ & $\begin{array}{l}0.085 \\
(0.07)\end{array}$ & $\begin{array}{l}0.186 \\
(0.15)\end{array}$ & $\begin{array}{c}-0.045 \\
(0.13)\end{array}$ & $\begin{array}{c}-0.045 \\
(0.13)\end{array}$ & $\begin{array}{c}-0.045 \\
(0.11)\end{array}$ \\
\hline Yr to Maturity* Debt/assets & $\begin{array}{l}0.073 \\
(0.11)\end{array}$ & $\begin{array}{l}0.116 \\
(0.10)\end{array}$ & $\begin{array}{l}0.118 \\
(0.10)\end{array}$ & $\begin{array}{l}0.118 \\
(0.08)\end{array}$ & $\begin{array}{c}-0.276 \\
(0.21)\end{array}$ & $\begin{array}{l}0.142 \\
(0.14)\end{array}$ & $\begin{array}{l}0.142 \\
(0.13)\end{array}$ & $\begin{array}{l}0.142 \\
(0.11)\end{array}$ \\
\hline Macro Factors & & & & & & & & \\
\hline $\operatorname{Ln}(\triangle \mathrm{IPI})$ & $\begin{array}{c}-0.008 \\
(0.02)\end{array}$ & $\begin{array}{c}-0.015 \\
(0.02)\end{array}$ & $\begin{array}{c}-0.016 \\
(0.02)\end{array}$ & $\begin{array}{c}-0.016 \\
(0.02)\end{array}$ & $\begin{array}{c}0.187^{* * * *} \\
(0.04)\end{array}$ & $\begin{array}{l}0.079^{*} \\
(0.04)\end{array}$ & $\begin{array}{l}0.079^{*} \\
(0.04)\end{array}$ & $\begin{array}{l}0.079 \\
(0.04)\end{array}$ \\
\hline $\operatorname{Ln}(\triangle \mathrm{CPI})$ & $\begin{array}{c}-0.072^{* * *} \\
(0.02)\end{array}$ & $\begin{array}{c}-0.052^{*} \\
(0.03)\end{array}$ & $\begin{array}{c}-0.053^{*} \\
(0.02)\end{array}$ & $\begin{array}{c}-0.053 \\
(0.03)\end{array}$ & $\begin{array}{l}0.067 \\
(0.04)\end{array}$ & $\begin{array}{l}0.037 \\
(0.03)\end{array}$ & $\begin{array}{l}0.037 \\
(0.03)\end{array}$ & $\begin{array}{l}0.037 \\
(0.03)\end{array}$ \\
\hline GDP Growth & $\begin{array}{c}-0.013 \\
(0.95)\end{array}$ & $\begin{array}{c}-0.609 \\
(0.92)\end{array}$ & $\begin{array}{c}-0.627 \\
(0.88)\end{array}$ & $\begin{array}{c}-0.627 \\
(0.89)\end{array}$ & $\begin{array}{l}0.183 \\
(1.93)\end{array}$ & $\begin{array}{c}-0.642 \\
(1.41)\end{array}$ & $\begin{array}{c}-0.642 \\
(1.38)\end{array}$ & $\begin{array}{c}-0.642 \\
(1.19)\end{array}$ \\
\hline Slope (10- and 2-year) & $\begin{array}{c}-6.954 \\
(7.83)\end{array}$ & $\begin{array}{c}-5.035 \\
(6.76)\end{array}$ & $\begin{array}{c}-6.751 \\
(6.56)\end{array}$ & $\begin{array}{c}-6.751 \\
(7.46)\end{array}$ & $\begin{array}{c}-32.955^{* *} \\
(10.04)\end{array}$ & $\begin{array}{l}6.481 \\
(7.40)\end{array}$ & $\begin{array}{l}6.481 \\
(7.22)\end{array}$ & $\begin{array}{l}6.481 \\
(5.93)\end{array}$ \\
\hline _cons & $\begin{array}{l}0.441 \\
(1.07) \\
\end{array}$ & $\begin{array}{c}-5.905^{* * *} \\
(1.33) \\
\end{array}$ & $\begin{array}{c}-5.233^{* * *} \\
(1.14) \\
\end{array}$ & $\begin{array}{c}-5.233^{* * * *} \\
(1.32) \\
\end{array}$ & $\begin{array}{c}-3.852 \\
(3.21) \\
\end{array}$ & $\begin{array}{l}4.826 \\
(3.70) \\
\end{array}$ & $\begin{array}{l}5.391 \\
(3.58) \\
\end{array}$ & $\begin{array}{l}5.391 \\
(4.63) \\
\end{array}$ \\
\hline$N$ & 361 & 361 & 361 & 361 & 119 & 119 & 119 & 119 \\
\hline Adj. $\mathrm{R}^{2}$ & .291 & & .321 & & .230 & & .182 & \\
\hline Firm Fixed Effects & No & Yes & Yes & Yes & No & Yes & Yes & Yes \\
\hline Sector Fixed Effects & No & Yes & Yes & Yes & No & Yes & Yes & Yes \\
\hline Cluster (Time) & Yes & Yes & Yes & No & Yes & Yes & Yes & No \\
\hline
\end{tabular}




\begin{tabular}{|c|c|c|c|c|c|c|c|c|}
\hline & \multicolumn{4}{|c|}{ Conventional Bonds } & \multicolumn{4}{|c|}{ Sukuk } \\
\hline & [1] OLS & [2] RE & [3] FE & [4] FE-DR & [1] OLS & [2] RE & [3] FE & [4] FE-DR \\
\hline \multicolumn{9}{|l|}{ Firm-specific } \\
\hline ROA & $\begin{array}{c}-12.651 \\
(12.69)\end{array}$ & $\begin{array}{c}-13.362 \\
(12.01)\end{array}$ & $\begin{array}{c}-31.392^{* *} \\
(8.84)\end{array}$ & $\begin{array}{c}-31.392^{*} \\
(9.54)\end{array}$ & $\begin{array}{c}-24.144^{* * *} \\
(4.35)\end{array}$ & $\begin{array}{c}-1.740 \\
(4.12)\end{array}$ & $\begin{array}{c}-1.734 \\
(4.05)\end{array}$ & $\begin{array}{c}-1.734 \\
(3.59)\end{array}$ \\
\hline Capitalization & $\begin{array}{c}-7.557 \\
(5.52)\end{array}$ & $\begin{array}{c}-8.381 \\
(5.91)\end{array}$ & $\begin{array}{c}-13.253^{*} \\
(5.23)\end{array}$ & $\begin{array}{c}-13.253^{*} \\
(4.75)\end{array}$ & $\begin{array}{c}-6.414^{* * * *} \\
(0.65)\end{array}$ & $\begin{array}{c}-0.789 \\
(2.34)\end{array}$ & $\begin{array}{c}-0.763 \\
(2.31)\end{array}$ & $\begin{array}{c}-0.763 * * \\
(2.01)\end{array}$ \\
\hline Leverage & $\begin{array}{c}-16.908 \\
(8.94)\end{array}$ & $\begin{array}{c}-17.000 \\
(9.14)\end{array}$ & $\begin{array}{c}-17.646^{*} \\
(7.72)\end{array}$ & $\begin{array}{c}-17.646 \\
(8.00)\end{array}$ & $\begin{array}{c}-6.515^{* * *} \\
(1.15)\end{array}$ & $\begin{array}{c}-1.379 \\
(1.90)\end{array}$ & $\begin{array}{c}-1.371 \\
(1.88)\end{array}$ & $\begin{array}{c}-1.371 \\
(1.63)\end{array}$ \\
\hline Interest Coverage & $\begin{array}{c}-0.021 \\
(0.03)\end{array}$ & $\begin{array}{c}-0.022 \\
(0.03)\end{array}$ & $\begin{array}{c}-0.080^{*} \\
(0.03)\end{array}$ & $\begin{array}{c}-0.080^{* * *} \\
(0.02)\end{array}$ & $\begin{array}{c}0.073^{* * * *} \\
(0.02)\end{array}$ & $\begin{array}{l}0.011 \\
(0.02)\end{array}$ & $\begin{array}{l}0.011 \\
(0.02)\end{array}$ & $\begin{array}{l}0.011 \\
(0.01)\end{array}$ \\
\hline Ln (Size) & $\begin{array}{c}-0.874 \\
(0.75)\end{array}$ & $\begin{array}{c}-0.404 \\
(1.12)\end{array}$ & $\begin{array}{c}-0.206 \\
(0.69)\end{array}$ & $\begin{array}{c}-0.206 \\
(0.30)\end{array}$ & $\begin{array}{c}-0.760^{* * * *} \\
(0.04)\end{array}$ & $\begin{array}{c}-0.103 \\
(0.09)\end{array}$ & $\begin{array}{c}-0.103 \\
(0.09)\end{array}$ & $\begin{array}{c}-0.103 * * * \\
(0.06)\end{array}$ \\
\hline Volatility & $\begin{array}{c}-1.120 \\
(1.65)\end{array}$ & $\begin{array}{c}-1.109 \\
(1.71)\end{array}$ & $\begin{array}{c}-3.428^{*} \\
(1.49)\end{array}$ & $\begin{array}{c}-3.428^{*} \\
(1.03)\end{array}$ & $\begin{array}{c}1.000^{* * * *} \\
(0.19)\end{array}$ & $\begin{array}{c}-0.280 \\
(0.36)\end{array}$ & $\begin{array}{c}-0.280 \\
(0.35)\end{array}$ & $\begin{array}{c}-0.280 \\
(0.27)\end{array}$ \\
\hline Bond-/Sukuk-specific & & & & & & & & \\
\hline Ln (Year to Maturity) & $\begin{array}{l}2.552 \\
(1.56)\end{array}$ & $\begin{array}{l}2.915 \\
(1.79)\end{array}$ & $\begin{array}{l}6.358^{*} \\
(2.01)\end{array}$ & $\begin{array}{c}6.358^{* * *} \\
(0.89)\end{array}$ & $\begin{array}{c}-0.371 \\
(0.26)\end{array}$ & $\begin{array}{l}0.031 \\
(0.15)\end{array}$ & $\begin{array}{l}0.029 \\
(0.15)\end{array}$ & $\begin{array}{l}0.029 \\
(0.12)\end{array}$ \\
\hline Yr to Maturity* Debt/assets & $\begin{array}{l}0.632 \\
(0.52)\end{array}$ & $\begin{array}{l}0.479 \\
(0.61)\end{array}$ & $\begin{array}{c}-0.246 \\
(0.65)\end{array}$ & $\begin{array}{c}-0.246 \\
(0.31)\end{array}$ & $\begin{array}{l}0.242 \\
(0.16)\end{array}$ & $\begin{array}{l}0.209 \\
(0.14)\end{array}$ & $\begin{array}{l}0.213 \\
(0.14)\end{array}$ & $\begin{array}{l}0.213 \\
(0.12)\end{array}$ \\
\hline Macro Factors & & & & & & & & \\
\hline $\operatorname{Ln}(\triangle \mathrm{IPI})$ & $\begin{array}{c}-0.044 \\
(0.09)\end{array}$ & $\begin{array}{c}-0.057 \\
(0.09)\end{array}$ & $\begin{array}{c}-0.037 \\
(0.04)\end{array}$ & $\begin{array}{c}-0.037 \\
(0.02)\end{array}$ & $\begin{array}{c}-0.053 \\
(0.04)\end{array}$ & $\begin{array}{l}0.004 \\
(0.03)\end{array}$ & $\begin{array}{l}0.004 \\
(0.03)\end{array}$ & $\begin{array}{l}0.004 \\
(0.03)\end{array}$ \\
\hline $\operatorname{Ln}(\triangle \mathrm{CPI})$ & $\begin{array}{l}0.211 \\
(0.19)\end{array}$ & $\begin{array}{l}0.249 \\
(0.17)\end{array}$ & $\begin{array}{c}0.516^{* * *} \\
(0.15)\end{array}$ & $\begin{array}{c}0.516^{* * *} \\
(0.11)\end{array}$ & $\begin{array}{c}-0.061 \\
(0.05)\end{array}$ & $\begin{array}{c}-0.049 \\
(0.05)\end{array}$ & $\begin{array}{c}-0.049 \\
(0.05)\end{array}$ & $\begin{array}{c}-0.049 \\
(0.05)\end{array}$ \\
\hline GDP Growth & $\begin{array}{l}0.765 \\
(1.87)\end{array}$ & $\begin{array}{l}1.048 \\
(1.92)\end{array}$ & $\begin{array}{l}4.182^{*} \\
(1.80)\end{array}$ & $\begin{array}{l}4.182^{*} \\
(1.26)\end{array}$ & $\begin{array}{c}-0.639 \\
(1.51)\end{array}$ & $\begin{array}{c}-1.773 \\
(1.25)\end{array}$ & $\begin{array}{c}-1.778 \\
(1.23)\end{array}$ & $\begin{array}{c}-1.778 \\
(1.15)\end{array}$ \\
\hline Slope (10- and 2-year) & $\begin{array}{c}-152.330 \\
(74.88)\end{array}$ & $\begin{array}{c}-160.411^{*} \\
(70.52)\end{array}$ & $\begin{array}{c}-192.160^{* *} \\
(43.28)\end{array}$ & $\begin{array}{c}-192.160^{* *} \\
(39.56)\end{array}$ & $\begin{array}{c}2.526 \\
(10.05)\end{array}$ & $\begin{array}{c}-28.711^{* *} \\
(9.25)\end{array}$ & $\begin{array}{c}-28.673^{* *} \\
(9.11)\end{array}$ & $\begin{array}{c}-28.673^{*} \\
(9.11)\end{array}$ \\
\hline _cons & $\begin{array}{r}7.725 \\
(14.01) \\
\end{array}$ & $\begin{array}{r}1.584 \\
(18.45) \\
\end{array}$ & $\begin{array}{r}-0.486 \\
(10.83) \\
\end{array}$ & $\begin{array}{c}-0.486 \\
(7.12) \\
\end{array}$ & $\begin{array}{c}7.419^{* * * *} \\
(0.91) \\
\end{array}$ & $\begin{array}{c}-1.871 \\
(2.55) \\
\end{array}$ & $\begin{array}{c}-2.659 \\
(2.34) \\
\end{array}$ & $\begin{array}{c}-2.659 \\
(1.97) \\
\end{array}$ \\
\hline $\mathrm{N}$ & 45 & 45 & 45 & 45 & 116 & 116 & 116 & 116 \\
\hline Adj. $\mathrm{R}^{2}$ & .900 & & .956 & & .874 & & .142 & \\
\hline Firm Fixed Effects & No & Yes & Yes & Yes & No & Yes & Yes & Yes \\
\hline Sector Fixed Effects & No & Yes & Yes & Yes & No & Yes & Yes & Yes \\
\hline Cluster (Time) & Yes & Yes & Yes & No & Yes & Yes & Yes & No \\
\hline
\end{tabular}




\begin{tabular}{|c|c|c|c|c|c|c|c|c|}
\hline & \multicolumn{4}{|c|}{ Conventional Bonds } & \multicolumn{4}{|c|}{ Sukuk } \\
\hline & [1] OLS & [2] RE & [3] FE & [4] FE-DR & [1] OLS & [2] RE & [3] FE & [4] FE-DR \\
\hline \multicolumn{9}{|l|}{ Firm-specific } \\
\hline ROA & $\begin{array}{c}-13.065^{* * * *} \\
(0.85)\end{array}$ & $\begin{array}{l}-2.356 \\
(-1.42)\end{array}$ & $\begin{array}{c}-2.009 \\
(1.43)\end{array}$ & $\begin{array}{c}-2.009 \\
(1.80)\end{array}$ & $\begin{array}{l}-1.722 \\
(-0.66)\end{array}$ & $\begin{array}{l}1.849 \\
(0.67)\end{array}$ & $\begin{array}{l}1.751 \\
(0.65)\end{array}$ & $\begin{array}{l}1.751 \\
(0.53)\end{array}$ \\
\hline Capitalization & $\begin{array}{c}-1.507^{* * * *} \\
(0.24)\end{array}$ & $\begin{array}{l}-0.503 \\
(-1.12)\end{array}$ & $\begin{array}{c}-0.220 \\
(0.43)\end{array}$ & $\begin{array}{c}-0.220 \\
(0.55)\end{array}$ & $\begin{array}{l}-0.781 \\
(-1.96)\end{array}$ & $\begin{array}{c}-3.018^{* *} \\
(-2.62)\end{array}$ & $\begin{array}{c}-2.968^{* *} \\
(-2.83)\end{array}$ & $\begin{array}{c}-2.968^{* * *} \\
(-2.77)\end{array}$ \\
\hline Leverage & $\begin{array}{c}-1.900^{* * * *} \\
(0.32)\end{array}$ & $\begin{array}{c}-2.172^{* * *} \\
(-3.70)\end{array}$ & $\begin{array}{c}-2.073^{* * *} \\
(0.58)\end{array}$ & $\begin{array}{c}-2.073^{* *} \\
(0.69)\end{array}$ & $\begin{array}{c}-1.252^{* *} \\
(-2.78)\end{array}$ & $\begin{array}{c}-3.962^{* * *} \\
(-3.97)\end{array}$ & $\begin{array}{c}-4.157^{* * *} \\
(-3.65)\end{array}$ & $\begin{array}{c}-4.157^{* * * *} \\
(-4.24)\end{array}$ \\
\hline Interest Coverage & $\begin{array}{c}-0.000 \\
(0.00)\end{array}$ & $\begin{array}{c}0.000409 \\
(0.20)\end{array}$ & $\begin{array}{l}0.000 \\
(0.00)\end{array}$ & $\begin{array}{l}0.000 \\
(0.00)\end{array}$ & $\begin{array}{c}-0.0149^{* * * *} \\
(-3.84)\end{array}$ & $\begin{array}{c}-0.00311 \\
(-1.50)\end{array}$ & $\begin{array}{c}-0.00281 \\
(-1.47)\end{array}$ & $\begin{array}{c}-0.00281 \\
(-1.17)\end{array}$ \\
\hline Ln (Size) & $\begin{array}{c}-0.330^{* * * *} \\
(0.02)\end{array}$ & $\begin{array}{l}-0.175^{*} \\
(-2.29)\end{array}$ & $\begin{array}{c}-0.122 \\
(0.06)\end{array}$ & $\begin{array}{c}-0.122 \\
(0.06)\end{array}$ & $\begin{array}{c}-0.314^{* * * *} \\
(-10.95)\end{array}$ & $\begin{array}{c}-0.638^{* * *} \\
(-7.11)\end{array}$ & $\begin{array}{c}-0.648^{* * *} \\
(-6.78)\end{array}$ & $\begin{array}{c}-0.648^{* * * *} \\
(-6.32)\end{array}$ \\
\hline Volatility & $\begin{array}{c}0.757^{* * * *} \\
(0.17)\end{array}$ & $\begin{array}{l}0.274^{* * *} \\
(2.71)\end{array}$ & $\begin{array}{l}0.258^{*} \\
(0.10)\end{array}$ & $\begin{array}{l}0.258^{*} \\
(0.10)\end{array}$ & $\begin{array}{l}0.291 \\
(1.61)\end{array}$ & $\begin{array}{l}0.145 \\
(1.06)\end{array}$ & $\begin{array}{l}0.141 \\
(1.12)\end{array}$ & $\begin{array}{l}0.141 \\
(1.66)\end{array}$ \\
\hline Bond-/Sukuk-specific & & & & & & & & \\
\hline Ln (Year to Maturity) & $\begin{array}{c}-0.149^{* * *} \\
(0.05)\end{array}$ & $\begin{array}{c}-0.182^{* * *} \\
(-3.63)\end{array}$ & $\begin{array}{c}-0.200^{* * *} \\
(0.05)\end{array}$ & $\begin{array}{c}-0.200^{* * *} \\
(0.06)\end{array}$ & $\begin{array}{c}-0.0130 \\
(-0.38)\end{array}$ & $\begin{array}{c}0.0474 \\
(1.77)\end{array}$ & $\begin{array}{c}0.0466 \\
(1.79)\end{array}$ & $\begin{array}{c}0.0466 \\
(1.96)\end{array}$ \\
\hline Yr to Maturity* Debt/assets & $\begin{array}{l}0.087 \\
(0.05)\end{array}$ & $\begin{array}{c}0.311^{* * * *} \\
(6.57)\end{array}$ & $\begin{array}{c}0.403^{* * * *} \\
(0.06)\end{array}$ & $\begin{array}{c}0.403^{* * * *} \\
(0.08)\end{array}$ & $\begin{array}{c}0.00160 \\
(0.71)\end{array}$ & $\begin{array}{c}-0.00248 \\
(-0.80)\end{array}$ & $\begin{array}{c}0.00350 \\
(0.47)\end{array}$ & $\begin{array}{c}0.00350 \\
(0.48)\end{array}$ \\
\hline Macro Factors & & & & & & & & \\
\hline $\operatorname{Ln}(\triangle \mathrm{IPI})$ & $\begin{array}{c}-0.013 \\
(0.03)\end{array}$ & $\begin{array}{c}0.00213 \\
(0.08)\end{array}$ & $\begin{array}{l}0.004 \\
(0.02)\end{array}$ & $\begin{array}{l}0.004 \\
(0.03)\end{array}$ & $\begin{array}{c}-0.0132 \\
(-0.31)\end{array}$ & $\begin{array}{c}-0.00521 \\
(-0.17)\end{array}$ & $\begin{array}{c}-0.00538 \\
(-0.18)\end{array}$ & $\begin{array}{c}-0.00538 \\
(-0.14)\end{array}$ \\
\hline $\operatorname{Ln}(\triangle \mathrm{CPI})$ & $\begin{array}{l}0.017 \\
(0.02)\end{array}$ & $\begin{array}{l}0.0122 \\
(1.03)\end{array}$ & $\begin{array}{l}0.010 \\
(0.01)\end{array}$ & $\begin{array}{l}0.010 \\
(0.01)\end{array}$ & $\begin{array}{c}0.0572^{* * *} \\
(3.26)\end{array}$ & $\begin{array}{c}0.0306^{* * *} \\
(3.11)\end{array}$ & $\begin{array}{c}0.0319^{* * *} \\
(3.07)\end{array}$ & $\begin{array}{c}0.0319^{* * *} \\
(2.77)\end{array}$ \\
\hline GDP Growth & $\begin{array}{c}-1.412 \\
(1.46)\end{array}$ & $\begin{array}{l}-1.859 \\
(-1.72)\end{array}$ & $\begin{array}{c}-1.836 \\
(0.99)\end{array}$ & $\begin{array}{c}-1.836 \\
(0.95)\end{array}$ & $\begin{array}{l}-1.215 \\
(-0.53)\end{array}$ & $\begin{array}{l}-0.983 \\
(-0.61)\end{array}$ & $\begin{array}{l}-0.973 \\
(-0.62)\end{array}$ & $\begin{array}{l}-0.973 \\
(-0.62)\end{array}$ \\
\hline Slope (10- and 2-year) & $\begin{array}{c}-7.116 \\
(5.68)\end{array}$ & $\begin{array}{l}-3.792 \\
(-0.93)\end{array}$ & $\begin{array}{c}-5.402 \\
(4.07)\end{array}$ & $\begin{array}{c}-5.402 \\
(2.96)\end{array}$ & $\begin{array}{l}6.701 \\
(0.92)\end{array}$ & $\begin{array}{l}0.102 \\
(0.02)\end{array}$ & $\begin{array}{l}0.330 \\
(0.07)\end{array}$ & $\begin{array}{l}0.330 \\
(0.07)\end{array}$ \\
\hline Domestic dummy & $\begin{array}{c}-0.224^{* * * *} \\
(0.04)\end{array}$ & $\begin{array}{c}-0.807^{* * * *} \\
(-3.55)\end{array}$ & $\begin{array}{c}0.000 \\
(.)\end{array}$ & $\begin{array}{c}0.000 \\
(.)\end{array}$ & $\begin{array}{l}-0.237^{*} \\
(-2.67)\end{array}$ & $\begin{array}{l}0 \\
(.)\end{array}$ & $\begin{array}{c}0.000 \\
(.)\end{array}$ & $\begin{array}{c}0.000 \\
(.)\end{array}$ \\
\hline _cons & $\begin{array}{c}-0.030 \\
(0.34) \\
\end{array}$ & $\begin{array}{c}-1.018 \\
(0.73) \\
\end{array}$ & $\begin{array}{c}-2.771^{* * *} \\
(0.80) \\
\end{array}$ & $\begin{array}{c}-2.771^{* *} \\
(0.88) \\
\end{array}$ & $\begin{array}{l}-0.719 \\
(-1.07)\end{array}$ & $\begin{array}{c}4.388^{* * *} \\
(2.86)\end{array}$ & $\begin{array}{c}3.688^{* *} \\
(2.84)\end{array}$ & $\begin{array}{c}3.688^{* * *} \\
(3.39)\end{array}$ \\
\hline$N$ & 1455 & 1455 & 1455 & 1455 & 516 & 516 & 516 & 516 \\
\hline Adj. $R^{2}$ & 0.397 & & .094 & & 0.399 & & 0.131 & \\
\hline Firm Fixed Effects & No & Yes & Yes & Yes & No & Yes & Yes & Yes \\
\hline Sector Fixed Effects & No & Yes & Yes & Yes & No & Yes & Yes & Yes \\
\hline Cluster (Time) & Yes & Yes & Yes & No & Yes & Yes & Yes & No \\
\hline
\end{tabular}




\begin{tabular}{|c|c|c|c|c|c|c|c|c|}
\hline & \multicolumn{4}{|c|}{ Conventional Bonds } & \multicolumn{4}{|c|}{ Sukuk } \\
\hline & [1] OLS & [2] RE & [3] FE & [4] FE-DR & [1] OLS & [2] RE & [3] FE & [4] FE-DR \\
\hline \multicolumn{9}{|l|}{ Firm-specific } \\
\hline \multirow[t]{2}{*}{ ROA } & $-10.34 * * *$ & 1.008 & 1.272 & 1.272 & 1.052 & 0.287 & 0.659 & 0.659 \\
\hline & $(-8.55)$ & $(0.55)$ & $(0.73)$ & $(0.70)$ & $(0.36)$ & $(0.14)$ & $(0.34)$ & $(0.26)$ \\
\hline \multirow[t]{2}{*}{ Capitalization } & $-2.322 * * *$ & $-1.110 * * *$ & $-0.609 *$ & $-0.609 *$ & -0.292 & $-3.460^{* * * *}$ & $-2.692^{*}$ & -2.692 \\
\hline & $(-8.39)$ & $(-3.41)$ & $(-2.26)$ & $(-2.49)$ & $(-1.12)$ & $(-3.95)$ & $(-2.68)$ & $(-1.93)$ \\
\hline \multirow[t]{2}{*}{ Leverage } & $-2.696 * * *$ & $-1.649 * * *$ & $-1.090 *$ & $-1.090 * *$ & $1.011^{* *}$ & $-3.608^{* * *}$ & $-2.774^{* *}$ & $-2.774^{*}$ \\
\hline & $(-8.53)$ & $(-3.62)$ & $(-2.50)$ & $(-2.77)$ & $(2.80)$ & $(-4.67)$ & $(-3.07)$ & $(-2.31)$ \\
\hline \multirow[t]{2}{*}{ Interest Coverage } & $-0.0127^{* * *}$ & -0.00200 & -0.00185 & -0.00185 & $-0.0122^{* * *}$ & -0.000463 & -0.000796 & -0.000796 \\
\hline & $(-3.81)$ & $(-0.68)$ & $(-0.69)$ & $(-0.57)$ & $(-4.96)$ & $(-0.21)$ & $(-0.37)$ & $(-0.30)$ \\
\hline \multirow[t]{2}{*}{ Ln (Size) } & $-0.377^{* * * *}$ & $-0.141^{* *}$ & -0.0487 & -0.0487 & $-0.425^{* * *}$ & $-0.312^{* *}$ & $-0.278^{* *}$ & $-0.278^{*}$ \\
\hline & $(-18.88)$ & $(-3.04)$ & $(-1.54)$ & $(-1.79)$ & $(-22.08)$ & $(-2.83)$ & $(-2.72)$ & $(-2.66)$ \\
\hline \multirow[t]{2}{*}{ Volatility } & 0.275 & $0.188^{*}$ & $0.170^{*}$ & $0.170^{*}$ & 0.0143 & 0.128 & 0.133 & 0.133 \\
\hline & (1.97) & $(2.39)$ & $(2.20)$ & $(2.70)$ & $(0.15)$ & (1.46) & (1.53) & (1.63) \\
\hline \multicolumn{9}{|l|}{ Bond-/Sukuk-specific } \\
\hline \multirow[t]{2}{*}{ Ln (Year to Maturity) } & -0.0465 & -0.0424 & -0.0390 & -0.0390 & $0.325^{* * *}$ & $0.148^{*}$ & $0.161^{*}$ & $0.161^{*}$ \\
\hline & $(-0.75)$ & $(-0.64)$ & $(-0.60)$ & $(-0.53)$ & $(4.22)$ & $(2.15)$ & $(2.31)$ & $(2.31)$ \\
\hline \multirow[t]{2}{*}{ Yr to Maturity* Debt/assets } & 0.103 & 0.195 & 0.170 & 0.170 & $-0.776^{* *}$ & -0.249 & -0.310 & -0.310 \\
\hline & $(0.65)$ & $(1.32)$ & $(1.14)$ & $(1.01)$ & $(-3.10)$ & $(-1.19)$ & $(-1.45)$ & $(-1.73)$ \\
\hline \multicolumn{9}{|l|}{ Macro Factors } \\
\hline \multirow[t]{2}{*}{$\operatorname{Ln}(\triangle \mathrm{IPI})$} & 0.0494 & $0.0475^{*}$ & 0.0440 & 0.0440 & $0.0659^{*}$ & 0.0404 & 0.0403 & 0.0403 \\
\hline & $(1.67)$ & $(2.01)$ & $(1.94)$ & $(1.42)$ & $(2.44)$ & $(1.73)$ & $(1.72)$ & $(1.26)$ \\
\hline \multirow[t]{2}{*}{$\operatorname{Ln}(\triangle \mathrm{CPI})$} & 0.0381 & 0.0190 & 0.0183 & 0.0183 & $0.0356^{*}$ & 0.0102 & 0.0113 & 0.0113 \\
\hline & $(1.83)$ & $(1.35)$ & $(1.36)$ & $(1.31)$ & $(2.04)$ & $(0.83)$ & $(0.95)$ & $(0.84)$ \\
\hline \multirow[t]{2}{*}{ GDP Growth } & -1.860 & -1.956 & -1.933 & $-1.933^{*}$ & -1.478 & -0.944 & -0.961 & -0.961 \\
\hline & $(-1.38)$ & $(-1.89)$ & $(-2.00)$ & $(-2.08)$ & $(-1.13)$ & $(-0.89)$ & $(-0.89)$ & $(-0.91)$ \\
\hline \multirow[t]{2}{*}{ Slope (10- and 2- year) } & 3.394 & 6.046 & 6.771 & 6.771 & -0.391 & 1.704 & 2.815 & 2.815 \\
\hline & $(0.50)$ & (1.09) & (1.24) & $(1.42)$ & $(-0.06)$ & $(0.38)$ & $(0.66)$ & $(0.52)$ \\
\hline \multirow[t]{2}{*}{ _cons } & $1.435^{* * * *}$ & $-3.245^{* * *}$ & $-3.168^{* * *}$ & $-3.168^{* * *}$ & -0.729 & 0.883 & 0.380 & 0.380 \\
\hline & $(3.78)$ & $(-5.18)$ & $(-6.29)$ & $(-6.95)$ & $(-2.01)$ & $(0.56)$ & $(0.29)$ & $(0.26)$ \\
\hline$N$ & 361 & 361 & 361 & 361 & 119 & 119 & 119 & 119 \\
\hline Adj. $\mathrm{R}^{2}$ & .432 & & .026 & & .448 & & .097 & \\
\hline Firm Fixed Effects & $\mathrm{No}$ & Yes & Yes & Yes & $\mathrm{No}$ & Yes & Yes & Yes \\
\hline Sector Fixed Effects & $\mathrm{No}$ & Yes & Yes & Yes & No & Yes & Yes & Yes \\
\hline Cluster (Time) & Yes & Yes & Yes & $\mathrm{No}$ & Yes & Yes & Yes & $\mathrm{No}$ \\
\hline
\end{tabular}




\begin{tabular}{|c|c|c|c|c|}
\hline & [1] OLS & [2] RE & [3] FE & [4] FE-DR \\
\hline \multicolumn{5}{|l|}{ Firm-specific } \\
\hline \multirow[t]{2}{*}{ ROA } & $-11.82^{* * *}$ & 0.0555 & 0.817 & 0.817 \\
\hline & $(-11.80)$ & $(0.03)$ & $(0.46)$ & $(0.44)$ \\
\hline \multirow[t]{2}{*}{ Capitalization } & $-2.003^{* * *}$ & $-1.427^{* * * *}$ & $-1.183^{* * *}$ & $-1.183^{* *}$ \\
\hline & $(-9.87)$ & $(-4.26)$ & $(-3.63)$ & $(-3.46)$ \\
\hline \multirow[t]{2}{*}{ Leverage } & $-2.204^{* * * *}$ & $-2.316^{* * * *}$ & $-2.106^{* * *}$ & $-2.106^{* * * *}$ \\
\hline & $(-8.51)$ & $(-5.67)$ & $(-4.88)$ & $(-5.11)$ \\
\hline \multirow[t]{2}{*}{ Interest Coverage } & 0.000309 & 0.00345 & 0.00306 & 0.00306 \\
\hline & $(0.18)$ & $(1.40)$ & $(1.34)$ & $(1.43)$ \\
\hline \multirow{2}{*}{ Ln (Size) } & $-0.337^{* * *}$ & $-0.236^{* * * *}$ & $-0.192^{* * *}$ & $-0.192^{* * * *}$ \\
\hline & $(-19.56)$ & $(-5.43)$ & $(-4.96)$ & $(-5.69)$ \\
\hline \multirow[t]{2}{*}{ Volatility } & $0.572^{* * * *}$ & $0.275^{* *}$ & $0.256^{*}$ & $0.256^{*}$ \\
\hline & $(4.03)$ & $(2.64)$ & $(2.59)$ & $(2.41)$ \\
\hline \multicolumn{5}{|l|}{ Bond-/Sukuk-specific } \\
\hline \multirow[t]{2}{*}{ Ln (Year to Maturity) } & 0.0160 & -0.000727 & -0.00289 & -0.00289 \\
\hline & $(0.93)$ & $(-0.03)$ & $(-0.13)$ & $(-0.10)$ \\
\hline \multirow[t]{2}{*}{ Yr to Maturity* Debt/assets } & -0.00308 & 0.000119 & 0.00931 & 0.00931 \\
\hline & $(-1.98)$ & $(0.09)$ & $(1.36)$ & $(1.07)$ \\
\hline \multicolumn{5}{|l|}{ Macro Factors } \\
\hline \multirow[t]{2}{*}{$\operatorname{Ln}(\triangle \mathrm{IPI})$} & 0.0184 & 0.0273 & 0.0274 & 0.0274 \\
\hline & $(0.68)$ & $(1.22)$ & $(1.30)$ & $(0.93)$ \\
\hline \multirow[t]{2}{*}{$\operatorname{Ln}(\triangle \mathrm{CPI})$} & 0.0121 & 0.00482 & 0.00368 & 0.00368 \\
\hline & $(0.74)$ & $(0.39)$ & $(0.30)$ & $(0.25)$ \\
\hline \multirow[t]{2}{*}{ GDP Growth } & -1.142 & -1.545 & -1.556 & -1.556 \\
\hline & $(-0.92)$ & $(-1.55)$ & $(-1.64)$ & $(-1.63)$ \\
\hline \multirow[t]{2}{*}{ Slope (10- and 2-year) } & -2.819 & -0.514 & -0.728 & -0.728 \\
\hline & $(-0.48)$ & $(-0.14)$ & $(-0.20)$ & $(-0.20)$ \\
\hline \multirow[t]{2}{*}{ CBONLY Dummy } & $0.130^{* * * *}$ & & & \\
\hline & $(4.34)$ & & & \\
\hline \multirow{2}{*}{ _cons } & 0.332 & $-2.432^{* * *}$ & $-1.508^{*}$ & $-1.508^{* *}$ \\
\hline & $(1.03)$ & $(-3.86)$ & $(-2.53)$ & $(-2.88)$ \\
\hline$N$ & 3210 & 3210 & 3210 & 3210 \\
\hline Adj. $R^{2}$ & .432 & & .026 & \\
\hline Firm Fixed Effects & No & Yes & Yes & Yes \\
\hline Sector Fixed Effects & No & Yes & Yes & Yes \\
\hline Cluster (Time) & Yes & Yes & Yes & No \\
\hline $\begin{array}{l}\text { Notes: The dependent varia } \\
0.001 \text {. The dependent variab } \\
\text { squares, (REM) [2] random } \\
\text { standard errors. }\end{array}$ & $\begin{array}{l}\text { ond } / s u k l \\
\text { nd ln }(s u \\
\text { 1) [3] fix }\end{array}$ & $\begin{array}{l}\text { dard err } \\
\text { convent } \\
\text { el, (FE- }\end{array}$ & $\begin{array}{l}\text { arenthes } \\
\text { and suk } \\
\text { 4] fixed }\end{array}$ & $\begin{array}{l}* \mathrm{p}<0.01 \\
\mathrm{OLS})[1] \\
\text { coll and } \mathrm{K}\end{array}$ \\
\hline
\end{tabular}




\section{Figure Appendix}

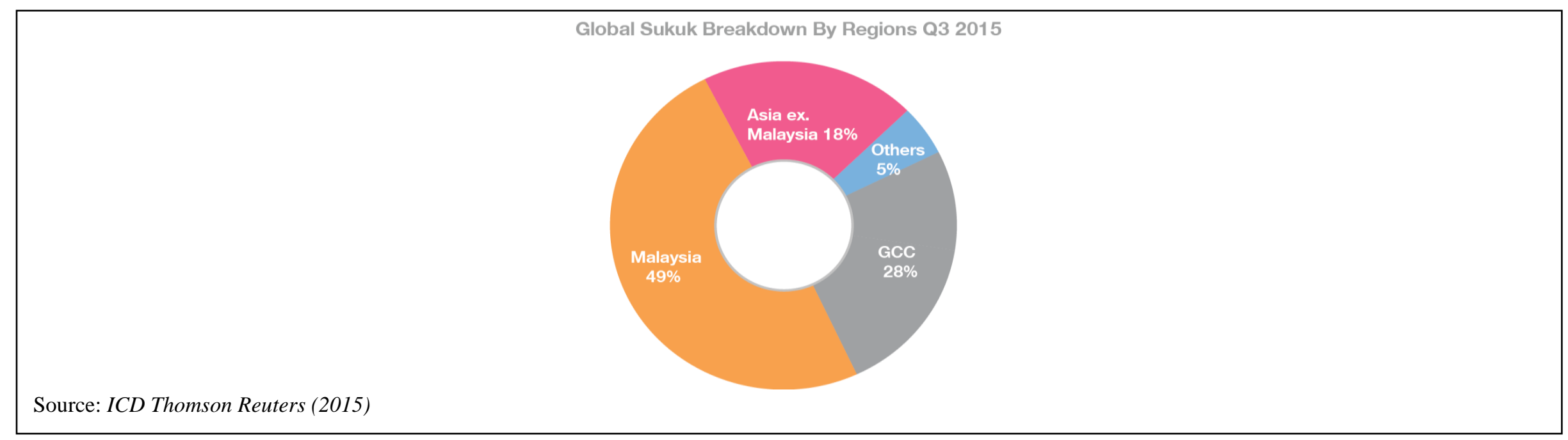

Figure 1a: Regional Breakdown of Sukuk Issuance

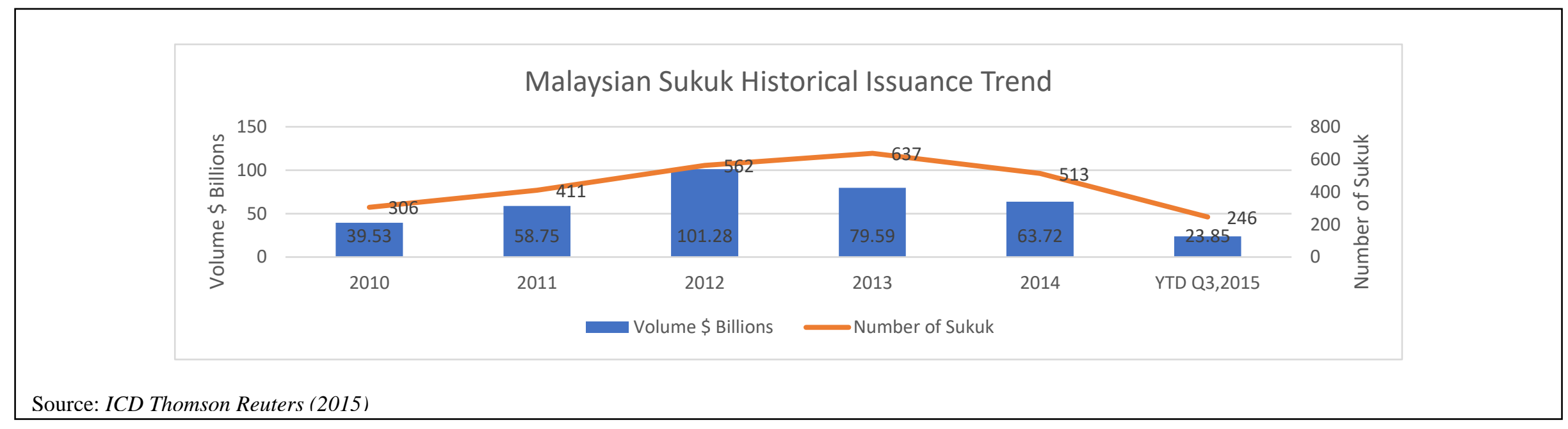

Figure 1b: Malaysian Sukuk Growth Trend 


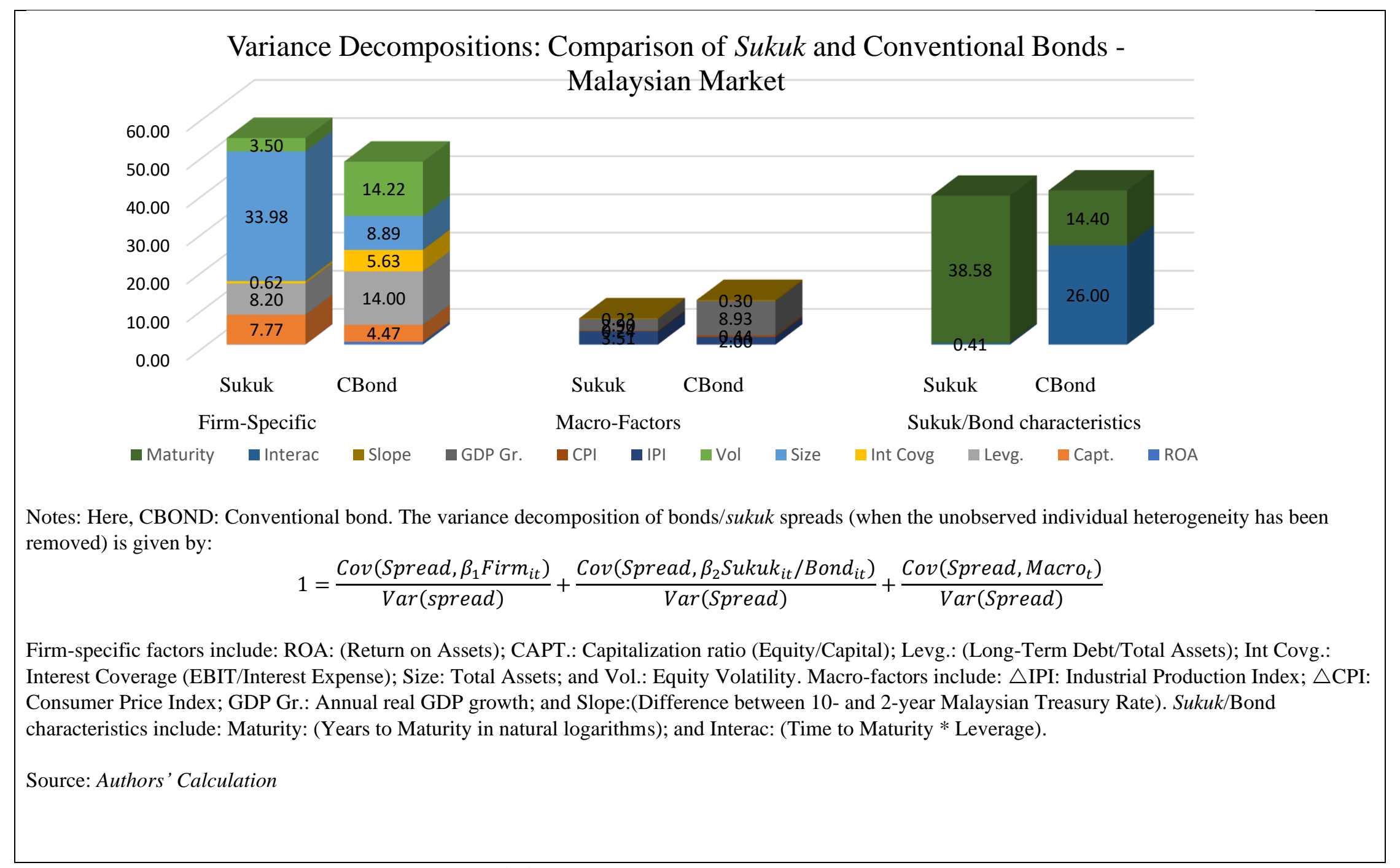

Figure 2: Variance Decompositions-Comparison of Sukuk and Conventional Bonds- Malaysian Bond Market 